\title{
Rho GTPase Regulators and Effectors in Autism Spectrum Disorders: Animal Models and Insights for Therapeutics
}

\author{
Daji Guo ${ }^{\circledR}$, Xiaoman Yang and Lei Shi * \\ JNU-HKUST Joint Laboratory for Neuroscience and Innovative Drug Research, College of Pharmacy, Jinan \\ University, Guangzhou 510632, China; daji0321@stu2017.jnu.edu.cn (D.G.); yxm3644@stu2018.jnu.edu.cn (X.Y.) \\ * Correspondence: t_shilei@jnu.edu.cn or sophielshi80@gmail.com; Tel.: +86-020-85222120
}

Received: 26 February 2020; Accepted: 26 March 2020; Published: 31 March 2020

\begin{abstract}
The Rho family GTPases are small G proteins that act as molecular switches shuttling between active and inactive forms. Rho GTPases are regulated by two classes of regulatory proteins, guanine nucleotide exchange factors (GEFs) and GTPase-activating proteins (GAPs). Rho GTPases transduce the upstream signals to downstream effectors, thus regulating diverse cellular processes, such as growth, migration, adhesion, and differentiation. In particular, Rho GTPases play essential roles in regulating neuronal morphology and function. Recent evidence suggests that dysfunction of Rho GTPase signaling contributes substantially to the pathogenesis of autism spectrum disorder (ASD). It has been found that 20 genes encoding Rho GTPase regulators and effectors are listed as ASD risk genes by Simons foundation autism research initiative (SFARI). This review summarizes the clinical evidence, protein structure, and protein expression pattern of these 20 genes. Moreover, ASD-related behavioral phenotypes in animal models of these genes are reviewed, and the therapeutic approaches that show successful treatment effects in these animal models are discussed.
\end{abstract}

Keywords: Rho GTPase; autism spectrum disorder; guanine nuclear exchange factor; GTPase-activating protein; animal model; behavior

\section{Introduction}

Autism spectrum disorder (ASD) is a neurodevelopmental disorder characterized by two core symptoms: (1) impaired social interaction and communication, and (2) repetitive or restricted interest and behaviors. The average global prevalence of ASD is $~ 0.62 \%$ [1], and studies in Europe and Asia have identified individuals with ASD with an average prevalence between $1 \%$ and $2 \%$ [2-6]. Statistics from CDC (Centers for Disease Control and Prevention)'s Autism and Developmental Disabilities Monitoring (ADDM) Network revealed that one in 59 children were diagnosed with ASD in United States in 2018 [7]. In addition, there is a high rate of co-occurring mental health disorders in ASD patients [8]. Meta-analysis of twin studies show that monozygotic twins have significantly higher concordance rate of ASD than dizygotic twins $[9,10]$, thus the aetiology of ASD is closely related to genetic component. However, the genetic causes of ASD are very complex as a huge number of genes contribute to the pathogenesis of ASD. Therefore, databases of ASD-related genes, such as SFARI (Simons foundation autism research initiative) Gene [11,12] and AutDB (the autism gene database) [13], have been established. With the development of genome sequencing, increasing genes related to ASD have been identified. As of November 2019, more than 800 genes have been included in SFARI Gene [14] and more than 1000 genes have been listed in AutDB [15]. Among these ASD susceptibility genes, many converge on synapse regulation such as the regulation of development and maturation of synaptic contacts and synaptic transmission [16-18]. 
In the nervous system, precise neuronal connectivity depends on synapses. It is well known that dendritic spines, which are enriched with filamentous actin, are dynamic structures important for synapse formation, function and plasticity [19]. Rho family GTPases are key regulators of the actin cytoskeleton that play critical roles in axonal outgrowth, dendritic spine morphogenesis, and synapse formation [20]. The Rho family GTPases, which belong to the Ras superfamily, are small G proteins sized $\sim 20 \mathrm{KDa}$. Human Rho family GTPases include 20 members that can be classified into eight groups [21,22]. By cycling between GTP-bound active forms and GDP-bound inactive forms, Rho GTPases regulate a diverse array of cellular events, including the control of growth, migration, adhesion, and differentiation. Rho GTPase activity is regulated by two different kinds of regulatory protein: guanine nucleotide exchange factors (GEFs), which catalyze the replacement of GDP by GTP, enabling the GTPases to recognize downstream effectors, and GTP-activating proteins (GAPs), which negatively regulate GTPase activity by favoring the GDP-bound forms $[19,23]$. Rho GTPase activity regulation is a complex process as 82 GEFs [24,25] and 66 GAPs (of which 57 have a common GAP domain) [26] have been identified so far in humans. The complexity of Rho GTPase signaling is also contributed by their downstream effectors, as there are over 70 downstream effectors identified to be capable of transducing signals from Rho GTPases [27].

A number of extensive review articles have summarized the impact of Rho family GTPases in neural development and diseases [23,28-33]. Moreover, multiple lines of evidence have suggested that Rho GTPase signaling may contribute to the pathogenesis of ASD. By searching SFARI Gene, it is notable to find that $8.53 \%$ (seven in 82 ) of RhoGEFs, $12.28 \%$ (seven in 57 ) of RhoGAPs and $8.21 \%$ (six in 73) Rho effectors are categorized as ASD-risk genes (Figure 1); $2.40 \%$ (20 in 831) ASD-risk genes directly participate in Rho GTPase signaling. We also find that all these genes encode regulatory proteins or effectors of three most-well studied Rho GTPases, Ras homolog family member A (RhoA), cell division cycle 42 (Cdc42), and Ras-related C3 Botulinum Toxin Substrate 1 (Rac1) (Table 1). In this review, the clinical evidence and animal models of these 20 genes are summarized. Moreover, therapeutic approaches that are capable of correcting the abnormalities caused by dysfunctions of these Rho GTPase regulators and effectors are discussed.

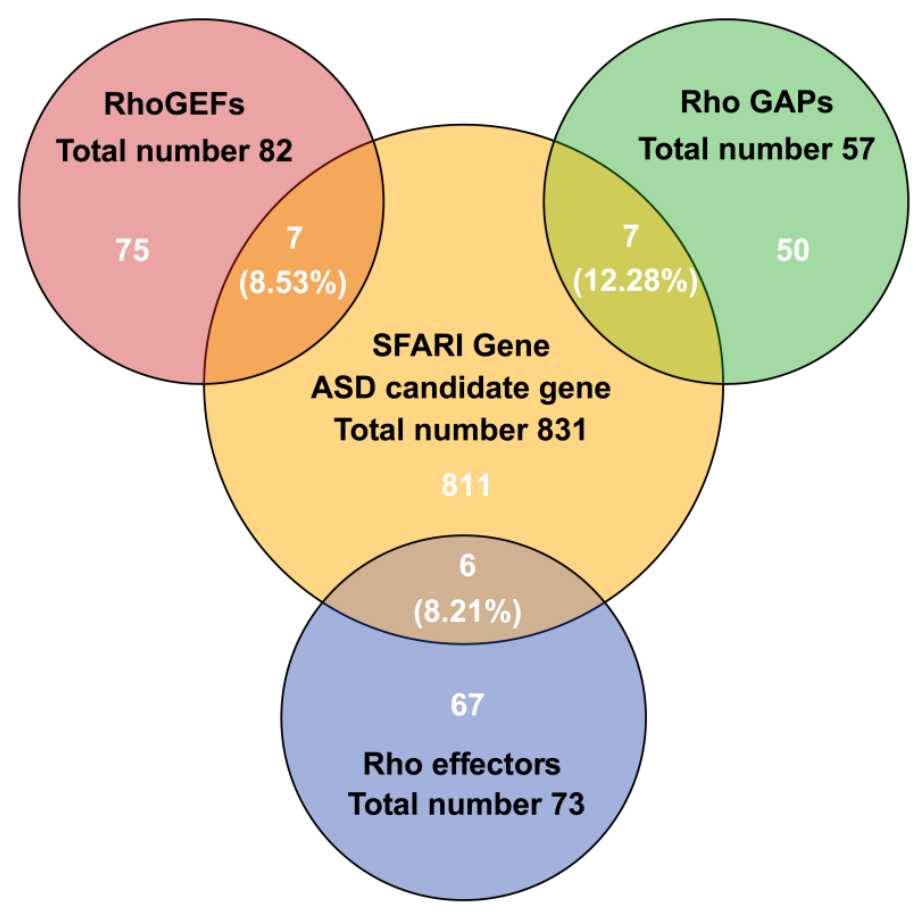

Figure 1. Overlap of human gene sets of RhoGEFs, RhoGAPs, and Rho effectors with autism spectrum disorder (ASD) risk genes in Simons foundation autism research initiative (SFARI). 
Table 1. Rho family GTPases involved in ASD.

\begin{tabular}{|c|c|c|c|c|c|}
\hline ASD Candidate Gene & Gene Name & Chromosome Location & Genetic Category & SFARI Gene Score & $\begin{array}{c}\text { Upstream/DOWNSTREAM Rho } \\
\text { GTPase(s) }\end{array}$ \\
\hline \multicolumn{6}{|c|}{ Rho GTPase GEF } \\
\hline ARHGEF9 & $\begin{array}{l}\text { Cdc42 guanine nucleotide exchange factor } \\
\text { (GEF) } 9\end{array}$ & Xq11.1-q11.2 & $\begin{array}{c}\text { Rare Single Gene } \\
\text { Mutation, Syndromic }\end{array}$ & $\begin{array}{l}\text { Category } 1 \text { (High } \\
\text { Confidence) }\end{array}$ & CDC42 \\
\hline TRIO & Trio Rho guanine nucleotide exchange factor & $5 \mathrm{p} 15.2$ & $\begin{array}{c}\text { Rare Single Gene } \\
\text { Mutation, Syndromic }\end{array}$ & $\begin{array}{l}\text { Category } 1 \text { (High } \\
\text { Confidence) }\end{array}$ & RHOA, RAC1 \\
\hline DOCK8 & Dedicator of cytokinesis 8 & $9 \mathrm{p} 24.3$ & $\begin{array}{l}\text { Rare Single Gene } \\
\text { Mutation }\end{array}$ & $\begin{array}{l}\text { Category } 2 \text { (Strong } \\
\text { Candidate) }\end{array}$ & CDC42 \\
\hline PREX1 & $\begin{array}{l}\text { Phosphatidylinositol-3,4,5-trisphosphate-dependent } \\
\text { Rac exchange factor } 1\end{array}$ & 20q13.13 & Genetic Association & $\begin{array}{l}\text { Category } 2 \text { (Strong } \\
\text { Candidate) }\end{array}$ & RAC1 \\
\hline ARHGEF10 & Rho guanine nucleotide exchange factor 10 & $8 \mathrm{p} 23.3$ & $\begin{array}{l}\text { Rare Single Gene } \\
\text { Mutation, Functional }\end{array}$ & $\begin{array}{c}\text { Category } 3 \text { (Suggestive } \\
\text { Evidence) }\end{array}$ & RHOA \\
\hline DOCK1 & Dedicator of cytokinesis 1 & $10 \mathrm{q} 26.2$ & $\begin{array}{l}\text { Rare Single Gene } \\
\text { Mutation }\end{array}$ & $\begin{array}{c}\text { Category } 3 \text { (Suggestive } \\
\text { Evidence) }\end{array}$ & RAC1 \\
\hline DOCK4 & Dedicator of cytokinesis 4 & $7 \mathrm{q} 31.1$ & $\begin{array}{c}\text { Rare Single Gene } \\
\text { Mutation, Genetic } \\
\text { Association, functional }\end{array}$ & $\begin{array}{c}\text { Category } 3 \text { (Suggestive } \\
\text { Evidence) }\end{array}$ & RAC1 \\
\hline \multicolumn{6}{|c|}{ Rho GTPase GAP } \\
\hline MҮO9B & Myosin IXB & 19p13.11 & $\begin{array}{l}\text { Rare Single Gene } \\
\text { Mutation }\end{array}$ & $\begin{array}{l}\text { Category } 2 \text { (Strong } \\
\text { Candidate) }\end{array}$ & RHOA \\
\hline OPHN1 & Oligophrenin 1 & Xq12 & $\begin{array}{c}\text { Rare Single Gene } \\
\text { Mutation, Syndromic }\end{array}$ & $\begin{array}{c}\text { Category } 2 \text { (Strong } \\
\text { Candidate) }\end{array}$ & RHOA, RAC1, CDC42 \\
\hline ARHGAP5 & Rho GTPase activating protein 5 & $14 \mathrm{q} 12$ & $\begin{array}{l}\text { Rare Single Gene } \\
\text { Mutation }\end{array}$ & $\begin{array}{c}\text { Category } 3 \text { (Suggestive } \\
\text { Evidence) }\end{array}$ & RHOA, RAC1, CDC42 \\
\hline ARHGAP11B & Rho GTPase activating protein 11B & $15 q 13.2$ & $\begin{array}{l}\text { Rare Single Gene } \\
\text { Mutation }\end{array}$ & $\begin{array}{c}\text { Category } 3 \text { (Suggestive } \\
\text { Evidence) }\end{array}$ & Unknown \\
\hline ARHGAP32 & Rho GTPase activating protein 32 & $11 \mathrm{q} 24.3$ & $\begin{array}{c}\text { Rare Single Gene } \\
\text { Mutation, Functional }\end{array}$ & $\begin{array}{c}\text { Category } 3 \text { (Suggestive } \\
\text { Evidence) }\end{array}$ & RHOA, RAC1, CDC42 \\
\hline SRGAP3 & SLIT-ROBO Rho GTPase activating protein 3 & $3 p 25.3$ & $\begin{array}{l}\text { Rare Single Gene } \\
\text { Mutation }\end{array}$ & $\begin{array}{c}\text { Category } 3 \text { (Suggestive } \\
\text { Evidence) }\end{array}$ & CDC42, RAC1 \\
\hline OCRL & Oculocerebrorenal syndrome of Lowe & Xq26.1 & $\begin{array}{l}\text { Rare Single Gene } \\
\text { Mutation, Syndromic }\end{array}$ & Syndromic & CDC42, RAC1 \\
\hline
\end{tabular}


Table 1. Cont.

\begin{tabular}{|c|c|c|c|c|c|}
\hline ASD Candidate Gene & Gene Name & Chromosome Location & Genetic Category & SFARI Gene Score & $\begin{array}{c}\text { Upstream/DOWNSTREAM Rho } \\
\text { GTPase(s) }\end{array}$ \\
\hline \multicolumn{6}{|c|}{ Rho GTPase Effector } \\
\hline NCKAP1 & NCK-associated protein 1 & $2 \mathrm{q} 32.1$ & $\begin{array}{l}\text { Rare Single Gene } \\
\text { Mutation }\end{array}$ & $\begin{array}{l}\text { Category } 1 \text { (High } \\
\text { Confidence) }\end{array}$ & RAC1 \\
\hline CYFIP1 & Cytoplasmic FMR1 interacting protein 1 & $15 q 11.2$ & $\begin{array}{c}\text { Rare Single Gene } \\
\text { Mutation, Genetic } \\
\text { Association, Functional }\end{array}$ & $\begin{array}{l}\text { Category } 2 \text { (Strong } \\
\text { Candidate) }\end{array}$ & RAC1 \\
\hline PAK2 & p21 (RAC1) activated kinase 2 & $3 q 29$ & $\begin{array}{l}\text { Rare Single Gene } \\
\text { Mutation }\end{array}$ & $\begin{array}{l}\text { Category } 2 \text { (Strong } \\
\text { Candidate) }\end{array}$ & CDC42, RAC1 \\
\hline ITPR1 & Inositol 1,4,5-trisphosphate receptor type 1 & $3 \mathrm{p} 26.1$ & $\begin{array}{l}\text { Rare Single Gene } \\
\text { Mutation }\end{array}$ & $\begin{array}{c}\text { Category } 3 \text { (Suggestive } \\
\text { Evidence) }\end{array}$ & RHOA \\
\hline PRKCA & Protein kinase $C$ alpha & $17 \mathrm{q} 24.2$ & $\begin{array}{l}\text { Rare Single Gene } \\
\text { Mutation }\end{array}$ & $\begin{array}{c}\text { Category } 3 \text { (Suggestive } \\
\text { Evidence) }\end{array}$ & RHOA, RAC1, CDC42 \\
\hline WASF1 & WAS protein family member 1 & $6 \mathrm{q} 21$ & Syndromic & Syndromic & RAC1 \\
\hline
\end{tabular}




\section{Rho Family GTPases and ASD}

Rho GTPases themselves have been rarely reported as risk genes of ASD. The only evidence so far is the linkage of RAC1 with ASD. Rac1 is an important Rho GTPase family member which regulates actin polymerization and spine remodeling through multiple signaling pathways, including PAKs (p21-activated kinases)-LIMK (LIM-domain-containing protein kinase)-cofilin [34], IRSp5 (insulin receptor substrate p53)-WAVE (Wiskott-Aldrich syndrome protein (WASP) family verprolin-homologous protein)-Arp2/3 [35,36], and PKA (protein kinase A) [37]. RAC1, encoding RAC1 and RAC1B, is a candidate gene for ASD listed in AutDB. Seven individuals with de novo mutations of $R A C 1$ were identified in patients of developmental disorders with divergent phenotypes [38]. One of these individuals displayed hyperactive behavior, two presented stereotypic movements, and one was diagnosed with autism [38]. Rac1 is highly expressed in embryonic cortex [39], and is ubiquitously expressed in the hippocampus, neocortex, thalamus, and cerebellum [40,41]. Rac1 is essential for the formation of three germ layers during gastrulation [42], and lack of which leads to embryonic lethality in Rac1 knockout (KO) mice. To understand the brain function of Rac1, several Rac1 conditional KO (cKO) mouse models have been constructed and studied. For instance, Foxg1-Cre mediated deletion of Rac1 in the ventricular zone (VZ) of telencephalon [43-45], Nkx2.1-Cre-mediated deletion in medial ganglionic eminence (MGE) [46], and Nestin-Cre-mediated deletion in precursors of neurons and glia during early embryonic stage [35] were used to study the important roles of Rac1 for brain development. Moreover, three studies investigated the behavioral changes in Rac1 cKO mouse models. Haditsch and colleagues generated a mouse model in which Rac1 is deleted in pyramidal neurons by Cre under CamKII $\alpha$ promoter to study the role of Rac1 in memory [47,48]. They demonstrated that loss of Rac1 in the hippocampus impairs long-term potentiation (LTP), and Rac1-deficient mice have impaired spatial memory and working or episodic-like memory [47]. They also found that the impaired working memory in these mice is due to prolonged memory retention or perseveration of the previously learned location [48]. Pennucci and colleagues generated a mouse model named Rac1N mice in which Rac1 is deleted in postmitotic neurons by Synapsin-I-Cre [49]. Rac1N mice show hyperactivity in several exploration tasks, impairment in spatial and working memory, and defects in retaining the context memory [49]. This study also reported failed synchronization of cortical networks in Rac1N mice by quantitative electroencephalogram (EEG). Moreover, spontaneous inhibitory synaptic currents (sIPSCs) are decreased in CA1 glutamatergic pyramidal cells in these mice [49]. However, these findings only focus on memory-related behaviors, but not the typical ASD-related ones such as social behaviors.

\section{RhoGEF Family and ASD}

There are 82 members of the human RhoGEF family, which are divided into two different subtypes: the classical Dbl family and the atypical Dock family [24]. So far, there are 71 members identified in Dbl RhoGEF family, which is characterized by a Dbl Homology (DH) domain, the catalytic GEF domain, and a Pleckstrin-Homology (PH) domain. The DH domain specifically catalyzes the exchange of GDP for GTP, whereas the role of PH domain varies considerably between different members, but is believed to facilitate the activation and localization of all Rho GTPases [25,50,51]. The Dock family, which contains 11 members, shows completely different structural features from the Dbl family. Dock family proteins have two main domains, the Dock homology region (DHR) 1 domain, which is responsible for phospholipid binding, and the DHR2 domain, which possesses the GEF activity [52]. Dock proteins are closely related to neurological disease [28,53]. By examining the overlap of RhoGEF genes and SFARI Gene, we find the following seven RHOGEFs as ASD-risk genes: ARHGEF9, TRIO, DOCK8, PREX1, ARHGEF10, DOCK1, and DOCK4 (see Appendix A) (Table 1).

\subsection{ARHGEF9 (SFARI Gene Score: 1, High Confidence)}

Rho guanine nucleotide exchange factor 9 (Arhgef9), also known as collybistin (CB), is a Dbl family GEF for Cdc42. ARHGEF9 is located on chromosome Xq11.1-q11.2. The first report on the 
linkage of ARHGEF9 with ASD identified a de novo microdeletion of Xq11.1 including entire ARHGEF9 in a male patient, who presented with severe intellectual disability (ID), epilepsy, and mild to moderate autism [54]. A second de novo mutation of ARHGEF9 was identified in a female patient diagnosed with ASD, ID and speech delay [55]. Subsequently, more de novo deletions of ARHGEF9 were found in patients with ASD co-occurring with developmental delay (DD) or other mental disorders [56-58], suggesting that ARHGEF9 is a strong candidate for ASD. Alternative splicing of Arhgef9 transcripts creates two CB variants, I and II [59]. CB I has typical domains of Dbl family that include an Src homology 3 domain (SH3), a PH and a DH domain followed by a predicted coiled-coil (CC) domain, whereas CB II lacks SH3 and CC domains [59,60] (Figure 2A). CB is expressed predominantly in the brain, with enrichment in the gray matter, cerebral cortex, hippocampus, and cerebellum [59,61,62]. It was found that the CB1 level is high during early brain developmental stage, whereas CB2 expression maintains high and constant levels throughout brain development [60]. CB KO mice exhibited elevated anxiety levels and impaired spatial memory (Table 2; Supplementary Table S1), and showed reduced GABAergic transmission, increased LTP, and decreased long-term depression (LTD) in hippocampal CA1 region [63]. Two studies using this mouse line investigated electrophysiological characteristics in hippocampal dentate gyrus (DG) region, demonstrating that CB plays an important role in maintaining normal granule cell excitability, GABAergic network inhibition, and synaptic plasticity $[64,65]$. 
Table 2. Summary of ASD-related behavior tests in Rho guanine nucleotide exchange factor (GEF), GTPase-activating protein (GAP), and effector mouse models.

\begin{tabular}{|c|c|c|c|c|c|c|c|c|c|}
\hline \multirow[b]{2}{*}{ Gene } & \multirow[b]{2}{*}{ Mouse Model } & \multicolumn{3}{|c|}{ Core Symptoms } & \multicolumn{4}{|c|}{ Comorbidities } & \multirow[b]{2}{*}{ Reference } \\
\hline & & $\begin{array}{l}\text { Social Related } \\
\text { Behavior }\end{array}$ & $\begin{array}{c}\text { Language } \\
\text { Communication }\end{array}$ & Repetitive Behavior & $\begin{array}{l}\text { Anxiety and } \\
\text { Depression }\end{array}$ & Learning and Memory & $\begin{array}{l}\text { Basic locomotion } \\
\text { and Motor } \\
\text { Coordination }\end{array}$ & $\begin{array}{l}\text { Schizophrenia } \\
\text { and Epilepsy }\end{array}$ & \\
\hline \multicolumn{10}{|c|}{ Summary of ASD-related behavior tests in Rho GEF mouse models } \\
\hline ARHGEF9 & Arhgef9 KO mice * & $\mathrm{NT}^{1}$ & NT & NT & Anxiety $\uparrow$ & $\begin{array}{l}\text { Spatial learning and } \\
\text { memory } \downarrow\end{array}$ & Activity - & NT & [63] \\
\hline \multirow{3}{*}{ TRIO } & Emx1-Trio ${ }^{-/-}$mice $\#$ & NT & NT & NT & NT & $\begin{array}{l}\text { Spatial learning and } \\
\text { memory } \downarrow \\
\text { Fear memory } \downarrow\end{array}$ & NT & NT & [66] \\
\hline & NEX-Trio ${ }^{+/-}$mice \& & Social preference $\downarrow$ & NT & $\begin{array}{l}\text { Nestlet shredding }\left(\mathrm{M}^{2} \text {, }\right. \\
\left.\qquad \uparrow ; \mathrm{F}^{3},-\right)\end{array}$ & $\begin{array}{c}\text { Anxiety } \uparrow \\
\text { Depression - }\end{array}$ & $\begin{array}{l}\text { Object recognition } \\
\text { memory - }\end{array}$ & $\begin{array}{c}\text { Activity } \downarrow \\
\text { Motor } \\
\text { coordination } \downarrow\end{array}$ & $\begin{array}{c}\text { Prepulse } \\
\text { inhibition - }\end{array}$ & \multirow{2}{*}{ [67] } \\
\hline & NEX-Trio $0^{-/-}$mice \& & Social preference $\downarrow$ & NT & $\begin{array}{l}\text { Nestlet shredding (M, } \uparrow \text {; } \\
\qquad,-)\end{array}$ & $\begin{array}{c}\text { Anxiety }(\mathrm{M}, \uparrow ; \mathrm{F}, \\
-) \\
\text { Depression } \uparrow\end{array}$ & $\begin{array}{l}\text { Object recognition } \\
\text { memory - }\end{array}$ & $\begin{array}{c}\text { Activity } \uparrow \\
\text { Motor } \\
\text { coordination } \downarrow\end{array}$ & $\begin{array}{c}\text { Prepulse } \\
\text { inhibition (M, } \\
\downarrow ; \mathrm{F},-)\end{array}$ & \\
\hline PREX1 & Prex $1^{-1-}$ mice * & $\begin{array}{c}\text { Social preference } \downarrow \\
\text { Social learning and } \\
\text { memory } \downarrow \\
\text { Olfactory function } \\
-\end{array}$ & $\begin{array}{l}\text { Ultrasonic } \\
\text { vocalizations } \\
\text { (pup) } \downarrow\end{array}$ & Grooming $\uparrow$ & Anxiety - & $\begin{array}{l}\text { Reversal learning } \downarrow \\
\text { Fear memory } \downarrow \\
\text { Object recognition } \\
\text { memory - }\end{array}$ & $\begin{array}{c}\text { Activity - } \\
\text { Motor } \\
\text { coordination - }\end{array}$ & $\begin{array}{l}\text { Prepulse } \\
\text { inhibition - }\end{array}$ & [68] \\
\hline ARHGEF10 & Arhgef10 KO mice * & $\begin{array}{c}\text { Sociability and } \\
\text { social novelty } \\
\text { preference } \downarrow\end{array}$ & NT & NT & $\begin{array}{c}\text { Anxiety } \downarrow \\
\text { Depression } \downarrow\end{array}$ & $\begin{array}{l}\text { Spatial learning and } \\
\text { memory - }\end{array}$ & Activity $\uparrow$ & $\begin{array}{l}\text { Prepulse } \\
\text { inhibition - }\end{array}$ & [69] \\
\hline \multirow[t]{2}{*}{ DOCK4 } & Dock 4 KO mice \& & $\begin{array}{c}\text { Social novelty } \\
\text { preference } \downarrow\end{array}$ & $\begin{array}{l}\text { Ultrasonic } \\
\text { vocalizations } \\
\text { (pup) } \downarrow\end{array}$ & $\begin{array}{c}\text { Stereotyped circling } \\
(\sim 9 \% \mathrm{~F} ; \mathrm{M},-) \\
\text { Marble burying (M, -; } \\
\text { F, NT) } \\
\text { Grooming (M, -; F, NT) }\end{array}$ & Anxiety $\uparrow$ & $\begin{array}{c}\text { Object recognition } \\
\text { memory (F, } \downarrow ; \mathrm{M},- \text { ) } \\
\text { Spatial memory (M, } \downarrow \text {; } \\
\text { F, -) } \\
\text { Working memory (M, } \downarrow \text {; } \\
\text { F, -) }\end{array}$ & $\begin{array}{c}\text { Activity }(\sim 9 \% \mathrm{~F}, \uparrow ; \\
\mathrm{M},-)\end{array}$ & NT & \multirow[t]{2}{*}{ [70] } \\
\hline & Dock4 HET mice \& & $\begin{array}{l}\text { Social novelty } \\
\text { preference } \\
(\mathrm{F}, \downarrow ; \mathrm{M},-)\end{array}$ & $\begin{array}{l}\text { Ultrasonic } \\
\text { vocalizations } \\
\text { (pup) - }\end{array}$ & $\begin{array}{c}\text { Stereotyped circling } \\
(\sim 1.7 \% \mathrm{~F} ; \mathrm{M},-) \\
\text { Marble burying (M, -; } \\
\text { F, NT) } \\
\text { Grooming (M, -; F, NT) }\end{array}$ & Anxiety - & $\begin{array}{c}\text { Object recognition } \\
\text { memory - } \\
\text { Spatial memory (F, } \downarrow ; \\
\mathrm{M},- \text { ) } \\
\text { Working memory - }\end{array}$ & $\begin{array}{l}\text { Activity }(\sim 1.7 \% \\
\text { F, } \uparrow ; \mathrm{M},-)\end{array}$ & NT & \\
\hline
\end{tabular}


Table 2. Cont

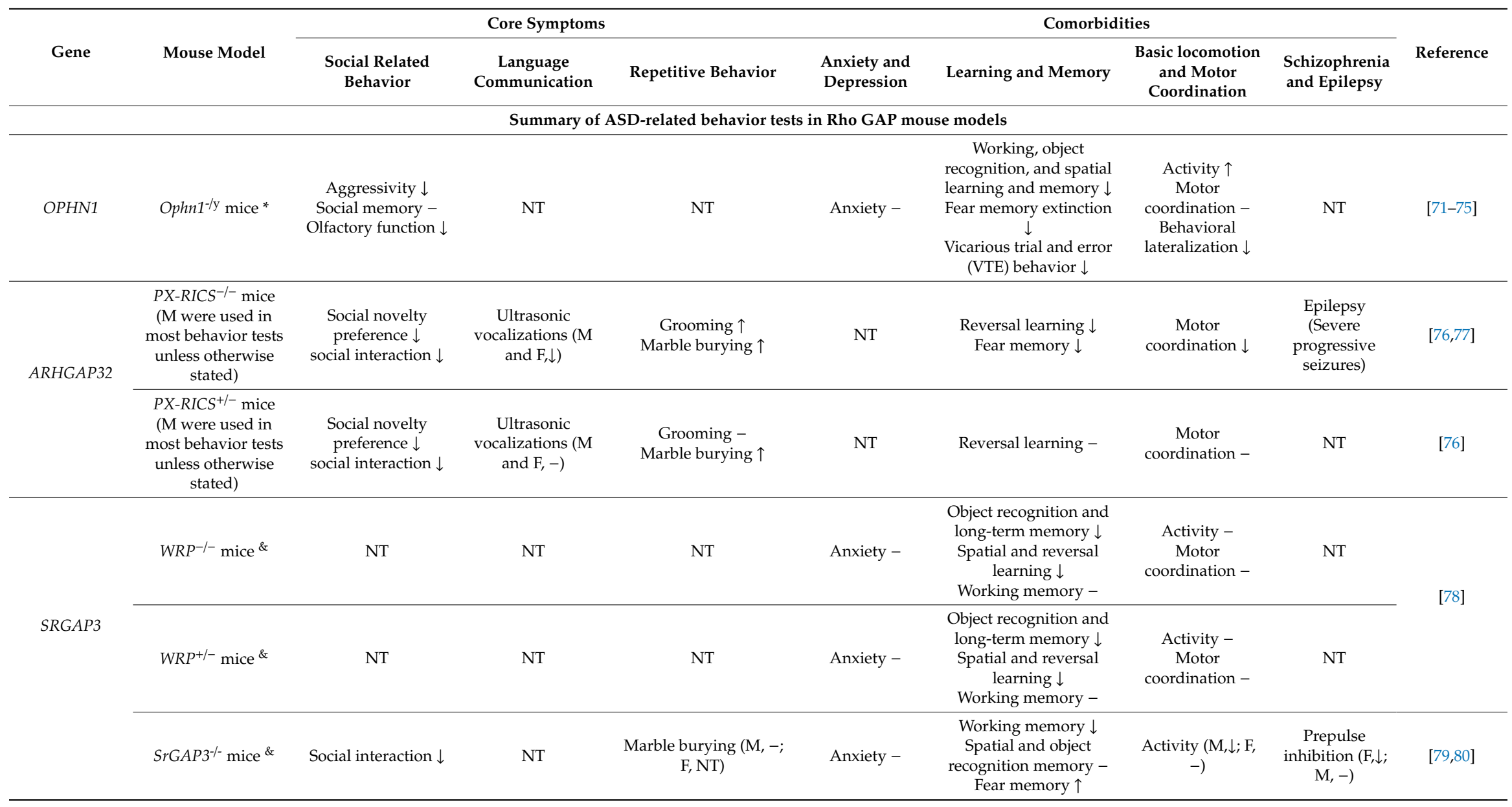


Table 2. Cont

\begin{tabular}{|c|c|c|c|c|c|c|c|c|c|}
\hline \multirow[b]{2}{*}{ Gene } & \multirow[b]{2}{*}{ Mouse Model } & \multicolumn{3}{|c|}{ Core Symptoms } & \multicolumn{4}{|c|}{ Comorbidities } & \multirow[b]{2}{*}{ Reference } \\
\hline & & $\begin{array}{l}\text { Social Related } \\
\text { Behavior }\end{array}$ & $\begin{array}{c}\text { Language } \\
\text { Communication }\end{array}$ & Repetitive Behavior & $\begin{array}{l}\text { Anxiety and } \\
\text { Depression }\end{array}$ & Learning and Memory & $\begin{array}{l}\text { Basic locomotion } \\
\text { and Motor } \\
\text { Coordination }\end{array}$ & $\begin{array}{l}\text { Schizophrenia } \\
\text { and Epilepsy }\end{array}$ & \\
\hline \multirow[b]{2}{*}{ OCRL } & Ocrl1 $1^{-/ y}$ mice * & NT & NT & NT & NT & $\begin{array}{l}\text { Passive avoidance } \\
\text { preference - }\end{array}$ & $\begin{array}{c}\text { Activity - } \\
\text { Motor } \\
\text { coordination } \downarrow\end{array}$ & NT & [81] \\
\hline & $\begin{array}{l}\text { Ocrl1 }^{-/ y} \text { mice } \\
\text { (Inpp5b deleted but } \\
\text { human INPP5B } \\
\text { overexpressed) }\end{array}$ & $\begin{array}{l}\text { Social preference - } \\
\text { Social novelty - }\end{array}$ & NT & NT & NT & $\begin{array}{l}\text { Spatial learning and } \\
\text { memory - }\end{array}$ & Activity $\downarrow$ & NT & [82] \\
\hline \multicolumn{10}{|c|}{ Summary of ASD-related behavior tests in Rho effector mouse models } \\
\hline \multirow{6}{*}{ CYFIP1 } & Cyfip1 HET mice * & Social interaction - & NT & NT & Anxiety - & $\begin{array}{c}\text { Hippocampus-dependent } \\
\text { memory } \downarrow \\
\text { Working, spatial, and } \\
\text { fearing memory - }\end{array}$ & Activity - & $\begin{array}{l}\text { Prepulse } \\
\text { inhibition - }\end{array}$ & [83] \\
\hline & Cyfip $1^{\mathrm{HET}}$ mice ${ }^{\#}$ & Social interest $\downarrow$ & $\begin{array}{c}\text { Ultrasonic } \\
\text { vocalizations - }\end{array}$ & Marble burying - & NT & NT & $\begin{array}{c}\text { Activity - } \\
\text { Motor } \\
\text { coordination } \downarrow\end{array}$ & NT & [84] \\
\hline & $\begin{array}{c}\text { Cyfip } 1 \mathrm{~m}+/ \mathrm{p}- \\
\text { (Paternal origin) } \\
\text { and Cyfip1 } \mathrm{m}-/ \mathrm{p}+ \\
\text { (maternal origin) } \\
\text { mice }\end{array}$ & NT & NT & NT & $\begin{array}{l}\text { Anxiety-like } \\
\text { behavior }\end{array}$ & $\begin{array}{l}\text { Fear memory }(\mathrm{m}+/ \mathrm{p}- \\
\quad \uparrow ; \mathrm{m}-/ \mathrm{p}+,-)\end{array}$ & $\begin{array}{l}\text { Activity }(\mathrm{m}+/ \mathrm{p}- \\
-; \mathrm{m}-/ \mathrm{p}+, \downarrow)\end{array}$ & NT & [85] \\
\hline & Cyfip $1^{+/-}$mice * & NT & NT & $\begin{array}{l}\text { Self-grooming - } \\
\text { Marble burying - }\end{array}$ & NT & $\begin{array}{c}\text { Spatial memory and } \\
\text { flexibility - } \\
\text { Object recognition } \\
\text { memory } \downarrow \\
\text { Working memory - }\end{array}$ & $\begin{array}{c}\text { Activity - } \\
\text { Motor } \\
\text { coordination } \downarrow\end{array}$ & $\begin{array}{c}\text { Prepulse } \\
\text { inhibition } \downarrow\end{array}$ & [86] \\
\hline & Cyfip $1^{+/-}$rat $*$ & NT & NT & NT & NT & Behavioral flexibility $\downarrow$ & NT & NT & [87] \\
\hline & $\begin{array}{l}\text { Human CYFIP1 } \\
\text { overexpressing } \\
\text { mice (Tg line } 1 \text { and } \\
\operatorname{Tg} \text { line } 2)^{\&}\end{array}$ & Social preference - & $\begin{array}{c}\text { Ultrasonic } \\
\text { vocalizations - }\end{array}$ & $\begin{array}{l}\text { Grooming - } \\
\text { Digging - }\end{array}$ & Anxiety - & $\begin{array}{c}\text { Fear memory (Line } 1 \\
\text { and line } 2, \uparrow \text { ) } \\
\text { Spatial learning } \\
\text { memory (Line } 2, \downarrow ; \text { line } \\
1,- \text { ) } \\
\text { Working memory (M } \\
\text { and F of both lines, }- \text { ) }\end{array}$ & Activity - & $\begin{array}{c}\text { Prepulse } \\
\text { inhibition - }\end{array}$ & [88] \\
\hline
\end{tabular}


Table 2. Cont.

\begin{tabular}{|c|c|c|c|c|c|c|c|c|c|}
\hline \multirow[b]{2}{*}{ Gene } & \multirow[b]{2}{*}{ Mouse Model } & \multicolumn{3}{|c|}{ Core Symptoms } & \multicolumn{4}{|c|}{ Comorbidities } & \multirow[b]{2}{*}{ Reference } \\
\hline & & $\begin{array}{l}\text { Social Related } \\
\text { Behavior }\end{array}$ & $\begin{array}{c}\text { Language } \\
\text { Communication }\end{array}$ & Repetitive Behavior & $\begin{array}{l}\text { Anxiety and } \\
\text { Depression }\end{array}$ & Learning and Memory & $\begin{array}{l}\text { Basic locomotion } \\
\text { and Motor } \\
\text { Coordination }\end{array}$ & $\begin{array}{l}\text { Schizophrenia } \\
\text { and Epilepsy }\end{array}$ & \\
\hline PAK2 & $P A K 2^{+/-}$mice * & $\begin{array}{l}\text { Social preference } \downarrow \\
\text { Social memory } \downarrow\end{array}$ & $\begin{array}{c}\text { Ultrasonic } \\
\text { vocalizations - }\end{array}$ & $\begin{array}{c}\text { Marble burying } \uparrow \\
\text { Grooming } \uparrow\end{array}$ & Anxiety - & $\begin{array}{l}\text { Spatial learning and } \\
\text { memory - }\end{array}$ & Activity - & $\begin{array}{l}\text { Prepulse } \\
\text { inhibition - } \\
\text { Acoustic } \\
\text { startle } \\
\text { response - }\end{array}$ & [89] \\
\hline \multirow{3}{*}{ ITPR1 } & $I P 3 R 1^{+/-}$mice \& & NT & NT & NT & NT & NT & $\begin{array}{c}\text { Activity - } \\
\text { Motor } \\
\text { coordination } \downarrow\end{array}$ & NT & [90] \\
\hline & $\begin{array}{l}\text { L7-Cre; Itpr flox/flox } \\
\text { mice }{ }^{\#}\end{array}$ & NT & NT & NT & NT & NT & $\begin{array}{c}\text { Motor } \\
\text { coordination } \downarrow\end{array}$ & NT & [91] \\
\hline & $\begin{array}{c}\text { Wht1-Cre; } \\
\text { Itpr } 1^{\text {flox/flox }} \text { mice }\end{array}$ & NT & NT & NT & NT & NT & $\begin{array}{c}\text { Motor } \\
\text { coordination } \downarrow\end{array}$ & NT & [92] \\
\hline \multirow[t]{2}{*}{ WASF1 } & WAVE-1 KO mice ${ }^{\#}$ & NT & NT & NT & Anxiety $\downarrow$ & $\begin{array}{c}\text { Spatial learning and } \\
\text { memory } \downarrow \\
\text { Object recognition } \\
\text { memory } \downarrow \\
\text { Passive avoidance - }\end{array}$ & $\begin{array}{l}\text { Activity } \downarrow \\
\text { Motor } \\
\text { coordination } \downarrow\end{array}$ & NT & \multirow[t]{2}{*}{ [93] } \\
\hline & WAVE-1 HET mice \# & NT & NT & NT & Anxiety - & $\begin{array}{c}\text { Learning and memory } \\
\qquad-\end{array}$ & $\begin{array}{c}\text { Activity } \downarrow \\
\text { Motor } \\
\text { coordination } \downarrow\end{array}$ & NT & \\
\hline
\end{tabular}

*: Only male were used in behavior tests; ${ }^{\&}:$ Both male and female mice were used in behavior tests; ${ }^{\#}$ : Mice gender was not mentioned; ${ }^{1} \mathrm{NT}$ : not tested; ${ }^{2} \mathrm{M}:$ male mice; ${ }^{3} \mathrm{~F}:$ female mice; $\uparrow$ is increased and $\downarrow$ is decreased; - is no change; More detailed information is shown in Supplementary Table S1. 


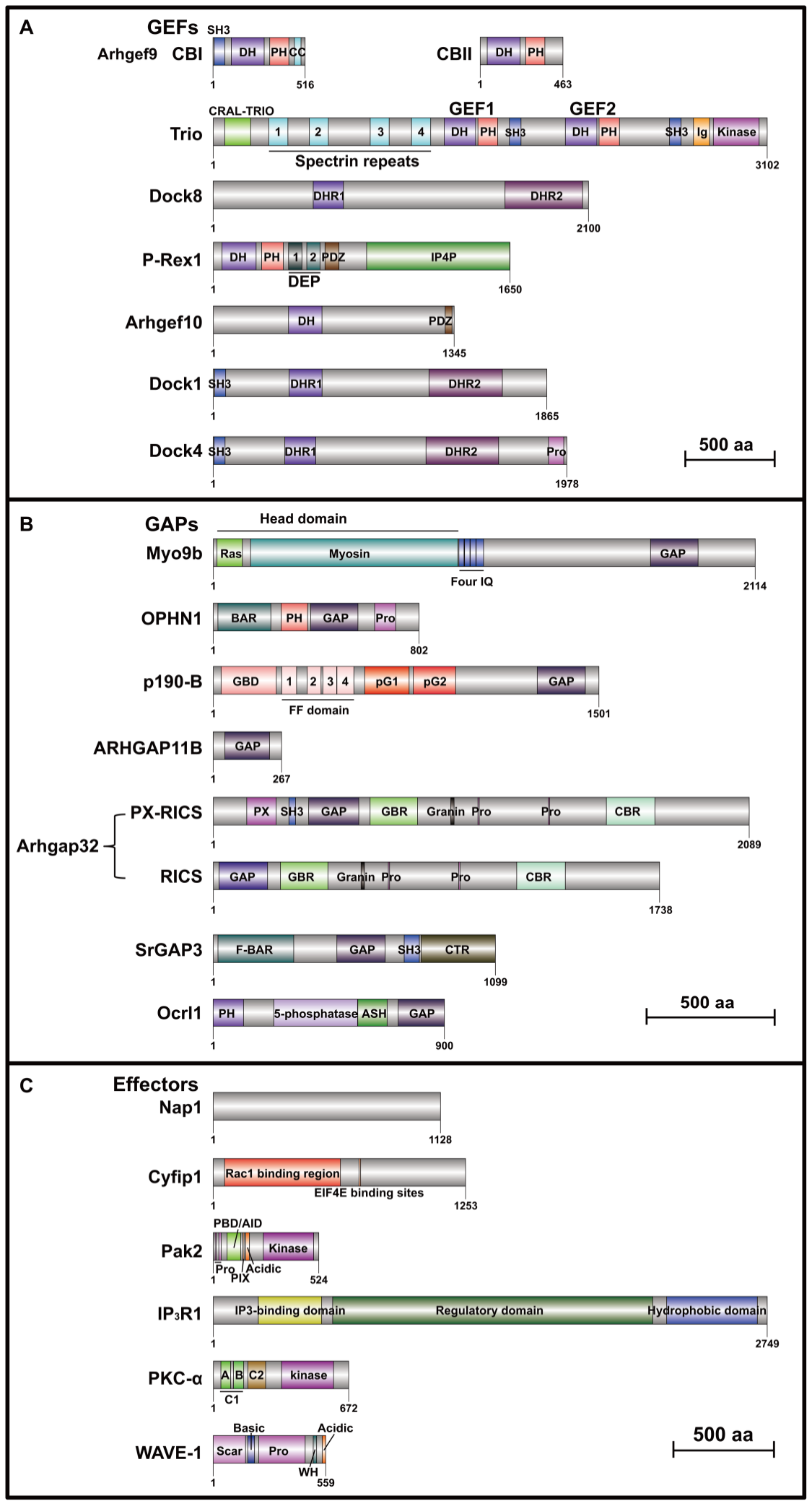

Figure 2. Schematics of protein domain structures of 20 ASD-related RhoGEFs, RhoGAPs, and Rho effectors. (A) Seven ASD-related RhoGEF protein domain architectures. Arhgef9 (which has two variants, 
CB I and CB II), Trio, P-Rex1, and Arhgef10 belong to Dbl family, which is characterized by a DH domain (dark violet) and a PH domain (light pink). Dock8, Dock1, and Dock4 belong to Dock family, which contains two main domains, DHR1 domain (dark orchid) and DHR2 domain (dark magenta). (B) Seven ASD-related RhoGAP protein domain architectures. In addition to a common catalytic GAP domain (purple), most RhoGAPs have multiple other functional domains. (C) Six ASD-related Rho effector protein domain architectures. All protein structures are generated using DOG 2.0 (Domain Graph, version 2.0) [94] based on corresponding mouse protein sequences except ARHGAP11B, for which human protein structure is shown as no homologs exist in rodents. Scales represent amino acid numbers of 500. AID, Autoinhibitory Domain; ASH, ASPM/SPD2/Hydin; BAR, Bin/Amphiphysin/Rvs; $\mathrm{C} 1$, binding site of diacylglycerol (DAG); $\mathrm{C} 2$, binding site of $\mathrm{Ca}^{2+} ; \mathrm{CBR}, \beta$-catenin-binding region; $\mathrm{CC}$, coiled-coil; CRAL-TRIO, cellular retinaldehyde-binding protein and TRIO guanine exchange factor; CTR, C-terminal region with proline-rich; DEP, Disheveled, EGL-10, Pleckstrin; DH, Dbl Homology; DHR1, Dock homology region 1; DHR2, Dock homology region 2; F-BAR, Fes-Cip4 homology Bin/Amphiphysin/Rvs; FF, domain with two conserved phenylalanine residues; GAP, GTPase-activating proteins; GBD, guanosine triphosphate (GTP)-binding; GBR, GABARAP-binding region; Ig, immunoglobulin; IP4P, inositol polyphosphate 4-phosphatase; IQ, short calmodulin-binding motif containing conserved isoleucine and glutamine residues; PBD, p21-binding domain; PDZ, PSD95/SAP90, DlgA, ZO-1; pG1, pseudoGTPase domain 1; pG2, pseudoGTPase domain 2; PH, Pleckstrin-Homology; PIX, Pak-interacting exchange factor; Pro, proline-rich; PX, phox homology; Scar, Scar homology; SH3, Src homology 3; WH, WASF homology.

\subsection{TRIO (SFARI Gene Score: 1, High Confidence)}

Trio Rho guanine nucleotide exchange factor (Trio), a large protein of the mammalian Dbl family, activates both Rac1 and RhoA. TRIO, located on chromosome 5p15.2, is a strong candidate gene for ASD. By using whole-exome sequencing (WES) and transmission and de novo association (TADA) analysis of rare coding variations, a study identified TRIO as a gene strongly enriched for variants likely to affect autism risk from 3871 autism cases [95]. Subsequently, several whole-exome and genome sequencing studies identified several TRIO variations in subjects with autism $[96,97]$ or ID co-occurring with autism [98,99]. Moreover, a large number of TRIO mutations leading to either reduced or excessive TIRO activity were found in ASD and neurodevelopmental disorder (NDD)/ASD/ID patients [100,101]. Trio protein contains two SH3 domains, a CRAL-TRIO (cellular retinaldehyde-binding protein and TRIO guanine exchange factor) domain, an immunoglobulin (Ig) domain, several spectrin-like repeats, two RhoGEF domains and a serine kinase domain [102] (Figure 2A). The GEF domain 1 activates Rac1 and RhoG, whereas the GEF domain 2 acts as an exchange factor for RhoA [103]. Because of the alternative splicing in Trio, Trio family is consisted of several isoforms, namely TrioA-E and Tgat $[102,104,105]$. Trio is enriched in the nervous system, and different isoforms are highly expressed in the cortex, hippocampus, striatum, and cerebellum, except for TrioC, which is highly expressed in the cerebellum [105]. Trio has important roles for embryonic development, as Trio ${ }^{-/}$mice die between embryonic day (E) 15.5 and birth [106]. Trio is also essential for brain development, because Trio ${ }^{\mathrm{NKO}}$ mice, in which the Trio is deleted in neuronal and glia progenitors by Nestin-Cre, have high death rate after birth; hypoplasia was found in the residual survival individuals with disruptive development of the cerebellum [107]. Two recent studies on deletion of Trio in the forebrain showed that these cKO mice can survive to adulthood. In one study, Emx1-Trio-- mice in which Trio deletion is restricted to the cerebral cortex and hippocampus show deficient spatial learning [66] (Table 2; Supplementary Table S1). In another study, Trio was deleted by NEX-Cre in neocortex and hippocampus starting from E11.5 [108]. Both NEX-Trio ${ }^{+/}$and NEX-Trio-/mice displayed impaired social preference and impaired motor coordination, and anxious behaviors were observed in all Trio mutant mice except female NEX-Trio-/- mice [67] (Table 2; Supplementary Table S1). Moreover, partial or full loss of Trio expression in motor cortex Layer 5 pyramidal neurons lead to disruption in presynaptic release probability, postsynaptic currents, and LTP [67]. However, the change in the ratio of NMDA ((N-methyl-D-aspartate)-type glutamate) receptor/AMPA 
( $\alpha$-amino-3-hydroxy-5-methyl-4-isoxazolepropionic acid) receptor-mediated excitatory postsynaptic currents (EPSCs) was opposite in these two mouse lines [67]. These findings show comprehensive phenotypic changes on behaviors and neural function by Trio deficiency. It was also found in vitro that gain-of-function forms of TRIO variants lead to increased Rac1 activity and synaptic AMPA receptor function, whereas loss-of-function forms lead to decreased Rac1 activity and AMPA receptor function $[100,101]$. However, gain-of-function Trio mouse models have not been generated and investigated for ASD pathology thus far.

Katrancha and colleagues found decreased levels of PDE4A5, a negative regulator of PKA signaling, and corresponding increased PKA signaling in NEX-Trio ${ }^{+-}$and NEX-Trio ${ }^{-/}$motor cortex [67]. To examine approaches for correcting the abnormalities caused by Trio deficiency, they transfected $\mathrm{Trio}^{+/ \text {flox }}$ neurons with GFP-P2A-Cre to establish Trio haploinsufficiency neurons as an in vitro model. These neurons showed increased spine density and decreased dendritic branch number, mimicking the phenotypes observed in NEX-Trio ${ }^{+-}$mouse brain [67]. Moreover, they treated the Trio deficient neurons with Rp-cAMPS, a competitive PKA antagonist, which reversed the increased dendritic spine density [67] (Table 3). For a non-pharmacological approach, PDE4A5 overexpression was capable of correcting the increased spine density but not branching deficits in Trio ${ }^{+-}$neurons [67] (Table 3). However, whether these two therapeutic approaches could rescue abnormal behaviors in NEX-Trio ${ }^{+/}$ mice has not been investigated.

Table 3. Treatments for Rho GTPase mouse models.

\begin{tabular}{|c|c|c|c|c|c|}
\hline Gene & $\begin{array}{l}\text { Mouse/Cellular } \\
\text { Model }\end{array}$ & Therapeutic Type & Therapeutic Strategy & Result & Reference \\
\hline \multirow[t]{2}{*}{ TRIO } & \multirow[t]{2}{*}{ Trio deficient neurons } & Pharmacological & $\begin{array}{l}\text { Rp-cAMPS treatment }(100 \\
\mu \mathrm{M})\end{array}$ & \multirow[t]{2}{*}{$\begin{array}{l}\text { Increased dendritic spine } \\
\text { density reversed }\end{array}$} & \multirow[t]{2}{*}{ [67] } \\
\hline & & Non-pharmacological & PDE4A5 overexpression & & \\
\hline \multirow[t]{2}{*}{$P-R E X 1$} & \multirow[t]{2}{*}{ Prex $1^{-/-}$mice } & Pharmacological & $\begin{array}{l}\text { D-serine (for } \\
\text { electrophysiology: } 20 \mu \mathrm{M} \text {; } \\
\text { for mouse: } 0.8 \mathrm{~g} / \mathrm{kg} \\
\text { i.p.(intraperitoneal)) }\end{array}$ & $\begin{array}{l}\text { NMDAR-LTD restored; } \\
\text { disruptive social novelty } \\
\text { corrected }\end{array}$ & \multirow[t]{2}{*}[68]{} \\
\hline & & Non-pharmacological & $\begin{array}{l}\text { WT P-Rex1 or WT Rac1 } \\
\text { overexpression (in CA1 } \\
\text { pyramidal neurons) }\end{array}$ & $\begin{array}{l}\text { NMDAR-LTD restored; } \\
\text { disruptive social novelty } \\
\text { and reversal learning } \\
\text { corrected }\end{array}$ & \\
\hline \multirow{3}{*}{ DOCK 4} & \multirow[t]{2}{*}{ Dock4 KO mice } & Pharmacological & $\begin{array}{l}\text { D-cycloserine (DCS, } 20 \\
\text { mg/kg i.p.) }\end{array}$ & Social novelty restored & \multirow[b]{2}{*}[70]{} \\
\hline & & Non-pharmacological & $\begin{array}{l}\text { WT Rac1 overexpression } \\
\text { (in CA1 region) }\end{array}$ & $\begin{array}{l}\text { Social novelty and } \\
\text { synapatic transmission } \\
\text { (mEPSC and LTP) } \\
\text { restored }\end{array}$ & \\
\hline & $\begin{array}{l}\text { Dock } 4 \text { knockdown } \\
\text { neurons }\end{array}$ & Non-pharmacological & WT Rac1 overexpression & $\begin{array}{l}\text { Decreased dendritic } \\
\text { spine density reversed }\end{array}$ & [109] \\
\hline \multirow{4}{*}{ OPHN1 } & \multirow{4}{*}{ Ophn1-/y mice } & \multirow{4}{*}{ Pharmacological } & $\begin{array}{l}\text { Rp-cAMPS (bilaterally } \\
\text { infused into PFC; } 10 \\
\mu \mathrm{g} / \mu \mathrm{L} ; 300-400 \mathrm{nl})\end{array}$ & $\begin{array}{l}\text { Cognitive dysfunction in } \\
\text { Y-maze ameliorated }\end{array}$ & {$[75]$} \\
\hline & & & \multirow[t]{2}{*}{$\begin{array}{l}\text { Fasudil (dissolved in daily } \\
\text { drinking water at } 0.65 \\
\mathrm{mg} / \mathrm{mL} \text { for } 3 \text { weeks) }\end{array}$} & $\begin{array}{l}\text { Spine morphology in } \\
\text { olfactory bulbs, } \\
\text { frequency and } \\
\text { amplitude of mIPSC in } \\
\text { olfactory neurons, and } \\
\text { olfactory behaviors } \\
\text { rescued }\end{array}$ & [73] \\
\hline & & & & $\begin{array}{l}\text { Fear memory extinction } \\
\text { restored }\end{array}$ & {$[74]$} \\
\hline & & & $\begin{array}{l}\text { Fasudil (orally a daily } \\
\text { dose of } 3 \mathrm{mg} \text { for } 3 \text { months) }\end{array}$ & $\begin{array}{l}\text { Locomotor activity and } \\
\text { object recognition } \\
\text { memory restored; } \\
\text { abnormal brain } \\
\text { morphology ameliorated }\end{array}$ & [72] \\
\hline
\end{tabular}


Table 3. Cont.

\begin{tabular}{|c|c|c|c|c|c|}
\hline Gene & $\begin{array}{c}\text { Mouse/Cellular } \\
\text { Model }\end{array}$ & Therapeutic Type & Therapeutic Strategy & Result & Reference \\
\hline ARHGAP32 & PX-RICS ${ }^{-/-}$mice & Pharmacological & $\begin{array}{l}\text { Clonazepam (CZP, } 0.03 \\
\mathrm{mg} / \mathrm{kg} \text { i.p.) }\end{array}$ & $\begin{array}{l}\text { Deficits of social } \\
\text { preference, reversal } \\
\text { learning, and cued fear } \\
\text { learning memory } \\
\text { reversed }\end{array}$ & {$[76,77]$} \\
\hline CYFIP1 & Cyfip $1^{\mathrm{HET}}$ mice & Non-pharmacological & $\begin{array}{l}\text { Motor training (at } \\
\text { postnatal days } 40,50 \text {, and } \\
51 \text { ) }\end{array}$ & Motor deficits alleviated & [84] \\
\hline ITPR1 & $\begin{array}{c}\text { Wnt1-Cre;Itpr } 1^{\text {flox/flox }} \\
\text { mice }\end{array}$ & Non-pharmacological & $\begin{array}{l}\text { Mating with Lurcher mice } \\
\left(G l u D 2^{\mathrm{LC} /+}\right)\end{array}$ & $\begin{array}{l}\text { Dystonic movements } \\
\text { eliminated }\end{array}$ & [92] \\
\hline
\end{tabular}

\subsection{DOCK8 (SFARI Gene Score: 2, Strong Candidate)}

Dedicator of cytokinesis 8 (Dock8) belongs to Dock-C subfamily, which lacks recognizable domains besides the DHR1-DHR2 module [28,110] (Figure 2A). Dock8 displays Cdc42-specific GEF activity [111,112]. DOCK8 is located on chromosome 9p24.3, which is identified as a linkage region in large autism extended pedigrees $[113,114]$. Moreover, multiple variants of DOCK8 are found in several genome sequencing studies on ASD patients [95,115-119]. Dock8 is primarily expressed in hematopoietic tissues, and Dock8 deficiency causes a combined immunodeficiency syndrome $[110,112,120]$. Recently, a study examined the expression of Dock8 in various cell types in the central nervous system (CNS), which reported that Dock8 is specifically expressed in microglia, but not neurons, astroglia, and retinal Müller glia [121]. A Dock8 KO mouse line has been generated, which showed abnormal microglial activity in retina [121]. However, the role of Dock8 in regulating neural behaviors has not been explored yet.

\subsection{PREX1 (SFARI Gene Score: 2, Strong Candidate)}

Phosphatidylinositol-3,4,5-trisphosphate-dependent Rac exchange factor 1 (P-Rex1) is a member of Dbl family. PREX1 is located on chromosome 20q13.13. A study on the Chinese Han population revealed that common variations in PREX1 are found in autistic individuals, and PREX1 mRNA levels are lower in the peripheral blood cells of autism subjects [68]. The main domain structures of P-Rex1 include a DH domain which has GEF activity, a PH domain which binds to PIP3 (phosphatidyl inositol $(3,4,5)$ trisphosphate), two DEP (Disheveled, EGL-10, Pleckstrin) and two PDZ (PSD95/SAP90, DlgA, ZO-1) protein interaction domains, and a C-terminal domain which is similar to IP4P (inositol polyphosphate 4-phosphatase) [122] (Figure 2A). P-Rex1 activates several RhoGEF family members in vitro, but it only activates the Rac family and RhoG in vivo [123]. A study showed that P-Rex1 is expressed mainly in peripheral blood leukocytes and the brain in human [124]. In the developing mouse brain, the expression of P-Rex1 is present in the cerebral cortex, hippocampus, olfactory bulbs, and the cerebellum [125], and P-Rex1 is expressed in different types of cell, including neurons, neural precursor cells, and glial cells [125]. Thus, P-Rex1 may have multiple roles in the nervous system. A study reported several motor behavioral deficits in $\operatorname{Prex}^{1^{-/}}$, Prex $2^{-/}$double-knockout mice [126]. A more recent study using a Prex $1 \mathrm{KO}$ mouse line investigated the behavioral, electrophysiological and biochemical changes after P-Rex1 is absent. These $\operatorname{Prex}^{-/-}$mice display core ASD-like features, including impaired social novelty and social memory, decreased ultrasonic calls in pups, increased time 
in grooming, and disrupted behavioral inflexibility [68] (Table 2; Supplementary Table S1). Moreover, mice with specific knockdown P-Rex1 in hippocampal CA1 region recapitulate the social defects and disrupted behavioral inflexibility in $\operatorname{Prex}^{{ }^{-/}}$mice [68]. The $\operatorname{Prex}^{-1-}$ mice exhibit impairment in NMDA receptors-dependent LTD in hippocampal neurons [68].

To examine therapeutic approaches to rescue abnormal social behaviors, D-serine, a selective full agonist of the glycine modulatory sites on the NMDA receptors, was examined [68]. Prex1 $1^{-/-}$mice treated with D-serine restore normal behavior of social novelty in the Three-chamber test. Moreover, NMDA receptor-dependent LTD impairment in Prex1 ${ }^{-/-}$mice is restored after D-serine treatment [68] (Table 3). As Prex1 ${ }^{-/}$mice show reduced Rac1 activity in the hippocampus [68], overexpression of Rac1 in the hippocampus of Prex1/- mice is able to correct the failure of social preference and reversal learning, and the disruption of NMDA receptors function [68] (Table 3). Furthermore, re-expressing P-Rex1 in Prex1/- mice also ameliorates impaired NMDA receptor-dependent LTD, deficient social behavior, and disruptive reversal learning [68] (Table 3).

\subsection{ARHGEF10 (SFARI Gene Score: 3, Suggestive Evidence)}

Rho guanine nucleotide exchange factor 10 (Arhgef10) belongs to the Dbl family, with a DH domain functioning as the GEF for RhoA and a putative PDZ-binding motif [127-129] (Figure 2A). ARHGEF10 is located on chromosome 8p23.3. Several de novo and inherited missense variants in ARHGEF10 have been identified in ASD patients $[95,119,130]$. Arhgef10 is ubiquitously expressed in the central and peripheral nervous system during embryonic development [131] and is widely expressed in the frontal cortex, striatum, hippocampus, and amygdala in adulthood [69]. An Arhgef10 $\mathrm{KO}$ mouse line has been generated, and the mice display defective sociability and social novelty, hyperactivity, and reduced levels of anxiety and depression [69] (Table 2; Supplementary Table S1).

\subsection{DOCK1 (SFARI Gene Score: 3, Suggestive Evidence)}

Dedicator of cytokinesis 1 (Dock1), a member of the Dock-A family, activates Rac1 by its DHR2 domain [132]. DOCK1 is located on chromosome 10q26.2. A genome-wide association study reported a loss-of-function variant of DOCK1 in the affected proband as well as the ASD-affected mother, but not in the unaffected sibling [133]. A recent study reported that two autistic siblings have unbalanced translocation on chromosome 10 which leads to DOCK1 deletion [134]. Dock1 consists of an SH3 domain, a DHR1 domain, and a DHR2 domain [132] (Figure 2A). The levels of Dock1 protein are downregulated during developmental stages in hippocampal neurons [135]. Dock1 has a critical role for embryonic development, and it has been shown that whole-body Dock1 KO mice are perinatal or neonatal lethal [136]. There have been no Dock1 cKO mouse models so far for the investigation of neuronal function and behavioral changes related to ASD.

\subsection{DOCK4 (SFARI Gene Score: 3, Suggestive Evidence)}

Dedicator of cytokinesis 4 (Dock4), a member of the Dock-B family, is an atypical Rac1 GEF. DOCK4 is located on chromosome 7q31.1 which belongs to AUTS1 (designated as autism susceptibility locus 1), in which several ASD-associated genes reside. A comprehensive single nucleotide polymorphism (SNP) genotyping, association and copy number variation study in Caucasian autism families identified the linkage between DOCK4 and ASD [137]. Several subsequent studies using SNP analysis reported multiple SNPs and chromosome microdeletions or duplications of DOCK4 in autism and/or dyslexia patients [138,139]. A summary of DOCK4 variations associated with ASD was provided in our previous study [70]. Dock4 contains an SH3 domain followed by a DHR1-DHR2 module, of which DHR2 is responsible for its GEF activity, and a proline-rich region [28] (Figure 2A). Dock4 is expressed at the highest level in the hippocampus, cortex, and cerebellum in adult rat brain [140], and the expression of Dock4 is upregulated along development in hippocampus in vivo and in hippocampal neurons cultured in vitro [140]. Our recent study used a Dock4 whole-body KO mouse line to investigate the phenotypes in behaviors, synapse transmission, and molecular alterations. We found that Dock4 KO 
mice display impaired social novelty preference, increased vocalizations, elevated anxiety levels, and disrupted spatial and working memory [70] (Table 2; Supplementary Table S1). Heterozygous (Dock4 HET) mice also show defective social novelty preference and disrupted spatial memory in Y-maze [70] (Table 2; Supplementary Table S1). Both male and female mice were studied in this study, and the Dock4 deficient mice show sex-dependent differences in anxiety levels and learning and memory. Notably, a small population of female Dock $4 \mathrm{KO}$ and HET mice exhibit repetitive circling behaviors in home cage and open field arena [70] (Table 2; Supplementary Table S1). Moreover, mice with specific KO of Dock4 in hippocampal CA1 region also exhibit defective social preference [70]. The hippocampal CA1 neurons of Dock 4 KO mice show impaired excitatory synaptic transmission especially NMDA receptor-dependent transmission, and decreased LTP [70].

As NMDA receptor impairment appeared to be responsible for the synaptic dysfunction in Dock4 KO hippocampus, a widely used NMDA receptor agonist D-cycloserine (DCS) was used as a pharmacological therapeutic strategy. Indeed, social novelty in the Three-chamber test was restored in Dock4 KO mice treated with DCS [70] (Table 3). For non-pharmacological therapeutic approaches, overexpressing Rac1 in hippocampus of Dock $4 \mathrm{KO}$ mouse corrects defective social preference and disruptive NMDA receptor function [70] (Table 3). Moreover, overexpressing Rac1 in cultured Dock4-knockdown hippocampal neurons also reverses the decreased spine density [109] (Table 3).

\section{RhoGAP Family and ASD}

To date, 66 RhoGAPs have been identified, most of which contain a common RhoGAP domain that has the catalytic GAP activity [141]. In addition, almost all RhoGAPs have at least two to three additional domains, which may interact with different proteins and are thus engaging the RhoGAPs in different signaling pathways [30,141]. RhoGAPs play irreplaceable roles in axonal and dendritic development, and synaptic plasticity $[19,30,31]$, disruption of which may contribute to the pathological mechanism of ASD. By overlapping 57 GAP domain-containing RhoGAP genes [26] with SFARI Gene, we find eight RHOGAPS as ASD-risk genes: MYO9B, OPHN1, ARHGAP5, ARHGAP11B, ARHGAP32, SRGAP3, and OCRL (Table 1).

\subsection{MYO9B (SFARI Gene Score: 2, Strong Candidate)}

Myosin IXB (Myo9b), a unique member of myosin family, contains a RhoGAP domain in its C-terminal tail, which stimulates the GTP hydrolysis of RhoA but not Cdc42 or Rac1 in vitro [142,143]. $M Y O 9 B$ is located on chromosome 19p13.11. Using WES and TADA analysis of rare coding variations of autism patients, $M Y O 9 B$ was identified as a gene strongly enriched for variants likely to affect autism risk [95]. Myo9b has a three-part structure: a head domain, four calmodulin-binding motifs containing conserved isoleucine and glutamine residues (IQ motifs) in the neck, and a RhoGAP tail [142,144] (Figure 2B). Human MYO9B is highly expressed in the immune system, and has minor levels in the respiratory system, digestive system, reproductive system, and nervous system [145]. As MYO9B is related to inflammatory bowel diseases [146] and celiac disease [147], the use of Myo9b KO mice has been mostly limited in studies of immune cells $[148,149]$. The role of Myo9b in the nervous system has been so far investigated in one study, which reported that Myo9b expression in the cerebral cortex reaches peak at around E18, and is decreased during development [150]. Knockdown of Myo9b in cultured cortical neurons or in developing cortex results in decreased dendrite length and number [150]. Nonetheless, the function of Moy $9 \mathrm{~b}$ in regulating neural behaviors has not been explored.

\subsection{OPHN1 (SFARI Gene Score: 2, Strong Candidate)}

Oligophrenin 1 (OPHN1) is a RhoGAP family member that is capable of inhibiting RhoA, Rac1, and Cdc42 in vitro without any specificity [151]. OPHN1 is located on chromosome Xq12 and is closely related to mental retardation (MR) and cerebellar hypoplasia [152]. Rare missense variants and rare hemizygous deletions in OPHN1 have been identified in ASD patients in different studies $[153,154]$. In recent exome sequencing studies, several de novo and maternally inherited 
variants of OPHN1 have been found in ASD patients with other mental disorders [99,155]. OPHN1 possesses a Bin/Amphiphysin/Rvs (BAR) dimerization domain and a PH domain at the N-terminus, followed by the GAP domain and the proline-rich region at the C-terminus [156,157] (Figure 2B). OPHN1 is ubiquitously expressed with highest levels in various brain regions, including the olfactory bulb, frontal lobes, sensory cortex, hippocampus, thalamus, and cerebellum [151,157], and its brain expression remains high throughout development [150,151,157]. Due to the central role of OPHN1 for

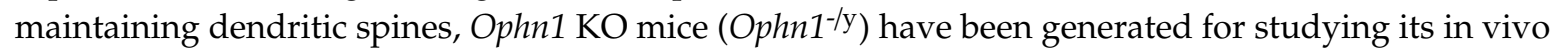
function. Ophn1/y mice show hyperactivity, decreased behavioral lateralization in paw preference test, altered spatial memory [71], and impaired object recognition memory [72] (Table 2; Supplementary Table S1). Furthermore, a study showed that Ophn1-/y mice are impaired in olfactory behavior [73], but another study reported that olfactory function is normal in the mice during social memory test [71] (Table 2; Supplementary Table S1). Lack of Ophn1 leads to decreased paired-pulse facilitation (PPF) in hippocampal CA1 neurons [71] and increased miniature inhibitory postsynaptic current (mIPSC) amplitude and frequency in olfactory neurons [73]. A further study revealed that Ophn1 ${ }^{-/ y}$ mice exhibit disruptive presynaptic plasticity at cortico-lateral amygdala and hippocampal synapses in a PKA dependent manner [74]. The abnormal presynaptic function leads to deficient fear memory extinction in Ophn1 ${ }^{-/ y}$ mice [74] (Table 2; Supplementary Table S1). Another recent study demonstrated that Ophn1/y mice display cognitive impairment in Y-maze spatial working memory test with high occurrence of perseverative behaviors [75] (Table 2; Supplementary Table S1), which suggests poor

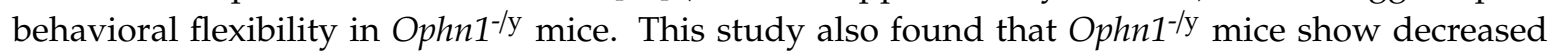
vicarious trial and error (VTE) behavior [75] (Table 2; Supplementary Table S1), which is a pause and look back and forth behavior reflecting a deliberation process during decision making in rodents [158].

Interestingly, the abnormal behaviors observed in $O p h n 1^{-/ y}$ mice are found to be resulted from PKA-dependent dysfunction of medial prefrontal cortex (mPFC) neuronal networks [75]. Consistently, increasing PKA activity in mPFC of WT mice causes similar impairments in Y-maze as observed in Ophn1 $1^{-/ y}$ mice [75]. Hence, local infusion of Rp-cAMPS, a competitive PKA antagonist, into mPFC of Ophn1/y ameliorates the spatial working memory deficits [75] (Table 3). Moreover, RhoA and its effector Rho kinase (ROCK) are well-studied downstream mediators of OPHN1 in vivo. As over-activation of the RhoA-ROCK pathway was observed in Ophn1 ${ }^{-/ y}$ mice [73], fasudil, a clinically approved inhibitor of ROCK as well as PKA, has been examined. Chronic fasudil treatment in Ophn1/y mice is able to reverse the alterations of spine morphology and mIPSC in olfactory neurons, and restore olfactory behaviors [73] (Table 3). Furthermore, chronic fasudil treatment restores fear memory extinction, locomotor activity, and object recognition memory in Ophn1-/y mice (Table 3), but it does not correct the abnormal working and spatial memory in these mice [72,74]. The abnormal brain morphology in $O p h n 1^{-/ y}$ mice, including the enlargement of brain lateral ventricles and the increase in hippocampal mushroom-shaped spines, are all ameliorated by fasudil treatment [72] (Table 3).

\subsection{ARHGAP5 (SFARI Gene Score: 3, Suggestive Evidence)}

Rho GTPase activating protein 5 (Arhgap5), also known as p190-B, is a member of the RhoGAP family that acts on inhibiting RhoA, Cdc42 and Rac1 [159,160]. ARHGAP5 is located on chromosome 14q12. Several de novo mutations in ARHGAP5, which lead to loss-of-function or missense variants, are found in genome sequencing studies [95,96,161]. From N- to C-terminus, p190-B is composed of a guanosine triphosphate (GTP)-binding domain (GBD), four FF domains, which characterize two conserved phenylalanine residues in each domain, two pseudoGTPase domains (pG1 and pG2), and a GAP domain [162,163] (Figure 2B). p190-B is highly expressed in the brain, stomach, and thymus [164]. A study on the expression pattern of RhoA GAPs shows that the protein level of p190-B is increased in the cerebral cortex during postnatal development [150]. p190-B plays an important role during embryonic development in the CNS [165,166] and hematopoietic system [167,168], and homozygous deletion of p190-B results in perinatal lethality [164]. However, mouse models in which p190-B 
is deficient in CNS are still missing for investigation of this protein on regulating neural function and behaviors.

\subsection{ARHGAP11B (SFARI Gene Score: 3, Suggestive Evidence)}

Rho GTPase activating protein 11B (ARHGAP11B) is a truncated version of ARHGAP11A, which contains 267 amino acids (aa) mostly comprised of a truncated GAP-domain and a unique C-terminal sequence [169] (Figure 2B). ARHGAP11B is located on chromosome 15q13.2. Copy number variations of $A R H G A P 11 B$ are found in patients with autism, ID [170], and schizophrenia (SCZ) [171]. Besides, a rare deletion overlapping ARHGAP11B is identified in monozygotic twins with SCZ [172]. Another study on 1257 autistic patients reported that loss of $A R H G A P 11 B$ is detected in eight patients, and two of them carry de novo deletions of SHANK2, a high risk gene of ASD [173]. ARHGAP11B is a human-specific gene with an important role in human neocortex expansion [174,175], especially for the amplification of basal radial glial cells. However, ARHGAP11B does not exhibit RhoGAP activity in vivo $[174,176]$, thus it may not truly belong to RhoGAP family. As there is no homolog gene of ARHGAP11B in rodents, it is not possible to investigate its function using rodent models.

\subsection{ARHGAP32 (SFARI Gene Score: 3, Suggestive Evidence)}

Rho GTPase activating protein 32 (Arhgap32), also designated as RICS, Grit, p200RhoGAP, p250RhoGAP, or GC-GAP, is a member of RhoGAP family. ARHGAP32 is located on chromosome 11q24.3. In a study of 17 patients with Jacobsen syndrome, also called 11q terminal deletion disorder, eight patients with autistic behaviors have $8.7-14.6 \mathrm{Mb}$ deletions of chromosome 11q, affecting four genes including ARHGAP32 [177]. Another study on 1543 Chinese ASD probands discovered the first de novo LGD (likely gene-disrupting) mutation in ARHGAP32 [115]. Recently, a study using single-molecule molecular inversion probes on ASD patients found an inherited mutation of ARHGAP32 [118]. Some studies showed that RICS possesses GAP activity toward Cdc42, Rac1, and RhoA equally [178,179], while others reported that RICS prefers RhoA and Cdc42 [180,181] or even only RhoA [182] as its substrate in vitro. RICS contains five domains, a GAP domain, a GABARAP-binding region (GBR), a granin motif (Granin), a polyproline stretch (Pro-rich), and a $\beta$-catenin-binding region (CBR) [183] (Figure 2B). RICS is abundant in the nervous system [178-182], especially in the cerebral11111 cortex, amygdala, thalamus, and hippocampus [181,184]. The expression of RICS in mouse brain reaches to peak at about postnatal day $(\mathrm{P}) 12$ during development, and is downregulated afterwards [185]. Similar expression pattern of RICS is also observed in cultured hippocampal neurons [185]. Immunofluorescent staining of cultured hippocampal neurons and immunoblotting of subcellular fractionations reveal that RICS is concentrated in the postsynaptic density $[179,181]$. Another longer spliced isoform of RICS, namely PX-RICS, has been reported, which has an additional phox homology (PX) domain and an SH3 domain in its N-terminal region [186] (Figure 2B). PX-RICS protein is also predominantly expressed in the nervous system [186], and at relatively low levels in the lung, kidney and spleen [186]. A RICS KO $\left(\mathrm{PX}^{\mathrm{RICS}}{ }^{-/}\right)$mouse line has been generated, in which both RICS and PX-RICS protein are absent [184]. PX-RICS ${ }^{-/}$mice exhibit defective social novelty preference, reduced passive social interaction, decreased ultrasonic calls in pups, increased repetitive behaviors, poor behavioral flexibility, impaired motor coordination, a seizure-prone phenotype, and abnormal cued fear learning memory [76,77] (Table 2; Supplementary Table S1). Moreover, PX-RICS ${ }^{+/-}$mice also exhibit moderate defects in social and repetitive behavior [76] (Table 2; Supplementary Table S1). Notably, PX-RICS-deficient hippocampal CA1 neurons show decreased mIPSC amplitude, suggesting impaired GABA ${ }_{A}$ R-mediated synaptic transmission in PX-RICS ${ }^{-1}$ mice [76]. Hence, clonazepam (CZP), a benzodiazepine agonist of $\mathrm{GABA}_{\mathrm{A}} \mathrm{R}$, was examined as a treatment for PX-RICS ${ }^{-/}$mice. Indeed, CZP administration leads to restoration of normal social preference and improved reversal learning and cued fear learning memory $[76,77]$ (Table 3 ). 


\subsection{SRGAP3 (SFARI Gene Score: 3, Suggestive Evidence)}

SLIT-ROBO Rho GTPase activating protein 3 (SrGAP3), also called mental disorder-associated GAP protein (MEGAP) and WAVE-associated RacGAP protein (WRP), is a member of RhoGAP family for Rac1 and Cdc42 but not RhoA [187,188]. SRGAP3 is located on chromosome 3p25.3. Two de novo missense variants in SRGAP3 are identified in ASD probands from a genome sequencing study [161]. SRGAP3 is also listed as a neurodevelopmental-disorder risk gene in ID patients co-occurring with autism [98]. SrGAP3 has four main domains including an N-terminal Fes-Cip4 homology Bin/Amphiphysin/Rvs (F-BAR) domain, a central GAP domain for its Rac1-GAP activity, a C-terminal SH3 domain, and a C-terminal region (CTR) with proline-rich motif $[189,190]$ (Figure 2B). Both human and mouse SrGAP3 is widely expressed in the whole CNS during embryonic development $[187,191,192]$, and highly expressed in the hippocampus, amygdala, thalamus, cortex, and cerebellum of the adult brain $[187,193]$. So far, two SrGAP3-deficient mouse models have been studied. First, a conditional SrGAP3 KO mouse model named WRP KO mice was generated, in which SrGAP3 is deleted by Nestin-Cre [78]. The WRP HET and KO mice both show impaired long-term memory and spatial memory in several behavior tests, and also display abnormal reversal learning in Morris water maze [78] (Table 2; Supplementary Table S1). Second, a SrGAP3-deficient mouse ( $\mathrm{SrGAP}^{-/-}$mice) was generated, in which an N-terminal 141 aa of SrGAP3 protein instead of the full length protein was expressed, mimicking the SRGAP3 deletion of a patient with severe ID [79]. The $S r G A P 3^{--}$male mice display hypoactivity, abnormal social exploration, and impaired working memory, whereas female mice show normal locomotion but severely impaired social behaviors (Table 2; Supplementary Table S1) and decreased prepulse inhibition (PPI) [79]. However, another study using this mouse model reported normal locomotion but reduced marble burying in SrGAP3--- male mice [80] (Table 2; Supplementary Table S1).

\subsection{OCRL (SFARI Gene Score: S, Syndromic)}

Inositol polyphosphate 5-phosphatase OCRL (Ocrl1), which encodes a type II phosphatidylinositol bisphosphate (PtdIns4,5 $\mathrm{P}_{2}$ ) 5-phosphatase, is a RhoGAP family member for Rac1 and Cdc42 [194]. OCRL is located on chromosome Xq26.1. Mutations in OCRL are related to Lowe syndrome, a multisystem disorders affecting eyes, the nervous system, and kidney [195]. An assessment of 52 male patients with Lowe syndrome using the Autism Screening Questionnaire found that $71.2 \%$ of patients met the cut-off score for ASD [196]. Moreover, a study has identified a full gene duplication of OCRL in a male ASD patient [197]. Ocrl1 has four main domains including a PH domain, a central 5-phosphatase domain, an ASPM/SPD2/Hydin (ASH) domain, and a C-terminal RhoGAP domain [198,199] (Figure 2B). Human OCRL1 is widely expressed in different tissues, with the highest levels observed in the brain, liver, and kidney [81]. A study showed that mice deficient with Ocrl1 alone fail to recapitulate the abnormalities observed in human [81] (Table 2; Supplementary Table S1). However, another mouse model with deletion of both Ocrl1 and another type II PtdIns4,5 $\mathrm{P}_{2}$ 5-phosphatase Inpp5b, but overexpression of human INPP5B display disorders related to Lowe syndrome [200]. Moreover, these mice show dysfunctional locomotor activity caused by muscular defects but normal sociability and learning memory [82] (Table 2; Supplementary Table S1), suggesting that this mouse model may not be used as an ASD model.

\section{Rho GTPase Effectors and ASD}

It is well known that Rho GTPases act as molecular switches that transduce upstream signals to downstream effectors to engage specific signaling cascades. Once in the GTP-bound active forms, the conformations of effector-binding regions of Rho GTPases are changed to allow interaction with the effectors [201]. This interaction regulates the function of effectors, resulting in a series of cell responses to the initial stimuli. There are a large number of molecules involved in Rho GTPase signaling, and more than 70 proteins have been identified as potential effectors of RhoA, Rac1, and Cdc42 [27]. 
We examine the overlap between these effector genes and SFARI Gene and find the following six effectors as ASD-risk genes: NCKAP1, CYFIP1, PAK2, ITPR1, PRKCA, and WASF1 (Table 1).

\subsection{NCKAP1 (SFARI Gene Score: 1, High Confidence)}

Nck-associated protein 1, also known as Nap1, is a component of the WAVE1/2 complex that interacts with activated Rac1 [202]. NCKAP1 is located on chromosome 2q32.1. A de novo LGD mutation of NCKAP1 has been identified in ASD probands [203]. Subsequently, several de novo or maternally inherited mutations in NCKAP1 are found in multiple WES studies on ASD probands $[95,161,204]$. Recently, two studies on Chinese and Caucasian ASD cohorts found more de novo LGD mutations in NCKAP1, which suggests that NCKAP1 is a strong candidate gene for ASD [115,205]. Nap1 does not contain any known functional motif [206] (Figure 2C). Human Nap1 is extensively expressed in multiple tissues except peripheral blood leukocytes, with highest expression detected in the brain, heart, and skeletal muscle [207]. The expression of human Nap1 is ubiquitously observed in all brain regions, with relatively higher levels in the cerebellum, hippocampus, and amygdala [207]. A study reported that human Nap1 is preferentially expressed in neuronal cells and may participate in neuronal apoptotic pathway [207]. Immunoblots from different embryonic ages indicate a pattern of developmentally increased Nap1 expression in the mouse cerebral cortex [208]. Yokota and colleagues found that knockdown of endogenous Nap1 leads to defective neuronal differentiation in mouse cortical neurons [208]. They then generated a Nap1 mutant mouse line in which the N-terminal 898 aa of Nap1 fused with a 1291 aa $\beta$-geo reporter is expressed instead of the full-length protein [208]. However, these Nap1 mutant mice are embryonic lethal from E8.5-E10.5 due to neural tube and neuronal differentiation defects [208]. Therefore, mouse models of Nap1 deficiency are still absent for the investigation of Nap1 on regulating neural behaviors.

\subsection{CYFIP1 (SFARI Gene Score: 2, Strong Candidate)}

Cytoplasmic FMR1 interacting protein 1 (Cyfip1), also named Shyc and Sra1, is a Rac1-interacting protein and a partner of the WAVE complex that regulates actin filament. CYFIP1 is located on chromosome 15q11.2. Several studies have reported that patients with 15q11.2 microdeletions and microduplications between breakpoints 1 and 2, which encompass several genes including CYFIP1, are diagnosed with neurodevelopmental disorders including ASD, ID, SCZ, attention-deficit/hyperactivity disorder (ADHD), and obsessive-compulsive disorder (OCD) [209-212]. A paternally inherited rare variant of CYFIP1 is found in an autistic patient with a de novo SHANK2 deletion [173]. Another paternally inherited rare variant of CYFIP1 is found in a study on high functioning ASD patients [213]. Additionally, SNPs in CYFIP1 were reported to correlate with ASD in two studies [214,215]. A study on CYFIP1 mRNA expression in human dorsolateral prefrontal cortex revealed higher expression of CYFIP1 mRNA in ASD and classical autism patients, and identified several common variants of CYFIP1 in these patients [216]. A recent study also demonstrated significant increase in CYFIP1 transcripts in the peripheral blood of ASD patients [217]. All these clinical findings reveal that altered CYFIP1 dosage may contribute to the pathology of ASD. Cyfip1 has been shown to interact with Rac1, Fragile X mental retardation 1 (FMRP), and eukaryotic translation initiation factor 4E (EIF4E) [218,219] (Figure 2C). Cyfip1 is widely expressed in multiple tissues but not liver during development and is highly enriched in the hippocampus, cerebral cortex, cerebellum, olfactory bulb, and lateral septum in the adult brain [220]. Levels of Cyfip1 are high in the cortex and cerebellum at the stages of postnatal development, peaked at P23 and slightly decreased afterwards [221].

Four different strategies have been used for generation of Cyfip1 KO mice. However, because Cyfip1 is very important for early embryonic development, none produce homozygous Cyfip1 KO mice. Therefore, Cyfip 1 HET mice are used for studying behavioral and neural phenotypes in these studies. The first mouse model was generated by mutagenesis with a gene trap vector inserted into intron 1 of Cyfip1. There are no Cyfip1 KO embryos in breeding [83]. Cyfip1 HET mice display normal learning and memory abilities in several memory tests, but show more rapid extinction in inhibitory 
avoidance test, a test for hippocampus-dependent memory [83] (Table 2; Supplementary Table S1). These results indicate that the accuracy of memory processing in HET mice is much poorer. Cyfip1 HET mice show increased mGluR-dependent LTD and abnormal presynaptic function in hippocampal slices $[83,222]$. The second one is generated by deleting exons 4-6 of Cyfip1. Inbreeded from Cyfip $1^{\mathrm{HET}}$ mice, fertilized Cyfip1 $\mathrm{KO}$ oocytes are detectable in blastocyst stage [223]. The $\mathrm{KO}$ embryos can survive until E8.5, but become lethal due to complete developmental failure [223]. The Cyfip ${ }^{\mathrm{HET}}$ mice show absence of interest for social cues and deficits in motor learning [84] (Table 2; Supplementary Table S1). The third one is generated by deleting exon 5 of $C y$ fip 1 , and the $C y f i p 1$ homozygous KO embryos die before E9.5 [85]. Moreover, the difference between the maternal $(\mathrm{m}-/ \mathrm{p}+)$ and paternal $(\mathrm{m}+/ \mathrm{p}-)$ deficiency of Cyfip 1 was investigated. Interestingly, Cyfip $1 \mathrm{~m}-/ \mathrm{p}+$ mice only display hypoactivity, whereas Cyfip $1 \mathrm{~m}+/ \mathrm{p}$ - mice display increased freezing in cued fear conditioning and abnormal transitions in zero-maze test [85] (Table 2; Supplementary Table S1). Both Cyfip1 m-/p+ mice and Cyfip $1 \mathrm{~m}+/ \mathrm{p}$ - mice show reduced field EPSC and increased PPF in hippocampal CA1 region, and enhanced mGluR-dependent LTD is observed in Cyfip $1 \mathrm{~m}+/ \mathrm{p}$ - mice hippocampal CA1 neurons [85]. The fourth one is generated by inserting a gene trap cassette between exon 12 and 13 of Cyfip1. Cyfip $1^{+/-}$ mice display impaired motor coordination, deficient sensory processing/novelty seeking behavior, reduced PPI, and decreased sensory motor gating [86] (Table 2; Supplementary Table S1), recapitulating some ASD and SCZ-like behavioral phenotypes. Cyfip $1^{+/-}$mice show reduced spontaneous neuronal activity and presynaptic function in cortical slices [86]. Besides the whole-body mutant mice, one Cyfip1 cKO mouse model (Cyfip $1^{\mathrm{NEX}}$ cKO mice) has been generated, in which exon 4-6 of Cyfip1 was deleted in forebrain excitatory neurons by NEX-Cre. These mice are viable until adulthood with no obvious abnormalities [224]. Cyfip $1^{\mathrm{NEX}}$ cKO mice show increased mIPSC amplitude in hippocampal CA1 neurons and display similar deficits in dendrite morphology and spine maturation to those described in Cyfip 1 haploinsufficient models [224]. There is also a Cyfip1 mutant rat model generated by CRISPR/Cas9 technology, in which a 4 bp heterozygous deletion is introduced in exon 7 of Cyfip1, causing premature stop of the protein [87]. These Cyfip1 haploinsufficient rats exhibit normal learning ability during all behavioral tests, but show deficits in behavioral flexibility [87] (Table 2; Supplementary Table S1). As increased transcript levels of CYFIP1 is found in some ASD patients, two transgenic (Tg) Cyfip1 mouse lines (Tg line 1 and $\mathrm{Tg}$ line 2) were generated by overexpressing human CYFIP1. mRNA of human CYFIP1 was increased in the cortex and hippocampus of both Tg lines; Cyfip1 protein is also increased in the two brain regions of $\mathrm{Tg}$ line 1 and the hippocampus of $\mathrm{Tg}$ line 2, but not in the cortex of $\mathrm{Tg}$ line 2 [88]. Behaviorally, $\mathrm{Tg}$ line 2 mice display subtle defects of spatial learning memory and obvious increased fear response in contextual and cued fear conditioning test, whereas $\mathrm{Tg}$ line 1 mice show normal spatial learning memory and increased freezing only to the tone in the novel context during fear conditioning test [88] (Table 2; Supplementary Table S1). However, both Tg lines show no deficits in core ASD-related behaviors such as social and repetitive behaviors [88] (Table 2; Supplementary Table S1). Together, Cyfip1 deficient mice or rats recapitulate core features of ASD, whereas Cyfip1 Tg mice may not be appropriate ASD models.

As increased mGluR activation was caused by Cyfip1 deficiency, mGluR1 inhibitor LY367385 and mGluR5 antagonist MPEP (2-Methyl-6-(phenylethynyl) pyridine) were used together. Indeed, these mGluR blockers normalized the mGluR-LTD to control levels in hippocampal slices of Cyfip 1 HET mice [83] (Table 3). However, the effect of these two inhibitors on behaviors has not been investigated. For non-pharmacological therapeutic approaches, motor training increased the number of newly formed dendritic spines in both WT and Cyfip $1^{\mathrm{HET}}$ mice, and the motor learning deficits in Cyfip $1^{\mathrm{HET}}$ mice can be alleviated by the behavioral training in early development but not in adult [84] (Table 3).

\subsection{PAK2 (SFARI Gene Score: 2, Strong Candidate)}

P21 activated kinase 2 (Pak2), activated by Rac1 and Cdc42, is a member of the group I PAK family that belongs to a family of serine/threonine kinases. PAK2 is located on chromosome 3q29, which is classified as one of six strong autism risk loci [225]. A study on six patients of 3q29 microdeletion 
syndrome identified a $\sim 1.5 \mathrm{Mb}$ microdeletion, which includes entire PAK2. Two of these patients displayed autistic features [226]. Another study on two patients of 3q29 microdeletion syndrome with common ID, a history of autism, and other psychiatric symptoms also reported the same length deletion [227]. In a subsequent study, 11 of 44 patients with 3q29 microdeletion syndrome were found to display diverse neurodevelopmental disorders including autism [228]. Moreover, one de novo copy-number deletion containing PAK2 was found in patients with ASD from the Simons Simplex Collection, and one de novo nonsense mutation and two inherited missense mutations were also found in PAK2 in 914 Han Chinese patients with ASD [89]. All these four studies reveal that PAK2 is a strong candidate for ASD. Pak2 has several recognized domains including two proline-rich regions and an AID (Autoinhibitory Domain) overlapping the PBD (p21-binding domain) in the N-terminal region, a kinase domain at the C-terminus, an acidic region, and a PIX (Pak-interacting exchange factor) binding site [229-231] (Figure 2C). Pak2 is ubiquitously expressed in multiple tissues [232]. Human PAK2 shows high expression levels in the brain during the fetal period and low levels after birth. Mouse Pak2 is also down-regulated at the postnatal development in the cortex [89]. Loss of Pak2 leads to embryonic lethality at $\sim$ E8 [232-234]. Therefore, a recent study used Pak2 ${ }^{+/-}$mice to investigate the behavioral and neural functional changes caused by Pak2 haploinsufficiency. This study revealed that $\mathrm{Pak2}^{+/-}$mice display repetitive and stereotyped behaviors, impaired social interaction, social avoidance, reduced social preference index, and disruptive social memory [89] (Table 2; Supplementary Table S1). $P a k 2^{+/-}$mice also exhibit decreased LTP in hippocampal CA1 region neurons [89]. Mechanistically, phosphorylation of both LIMK1, a major downstream target of group I PAKs, and its substrate cofilin were markedly decreased, suggesting abnormal LIMK1/cofilin-mediated actin polymerization in adult Pak2 ${ }^{+/-}$mice cortex [89]. To normalize endogenous p-cofilin levels in the cortex and hippocampus, a p-cofilin peptide was intravenously injected into adult $\mathrm{Pak}^{+/-}$mice as a substrate to compete with endogenous p-cofilin for phosphatases. As a result, this peptide moderately improved social behaviors but not repetitive behaviors in adult Pak2 ${ }^{+/-}$mice [89] (Table 3).

\subsection{ITPR1 (SFARI Gene Score: 3, Suggestive Evidence)}

Inositol 1,4,5-trisphosphate receptor type 1 , also known as $\mathrm{IP}_{3} \mathrm{R} 1$, is a RhoA effector. $\mathrm{IP}_{3} \mathrm{R} 1$ is a member of $\mathrm{IP}_{3} \mathrm{Rs}$, which are $\mathrm{Ca}^{2+}$ release channels on the endoplasmic reticulum. ITPR1 is located on chromosome 3p26.1. Three de novo missense variants in ITPR1 are found in ASD probands from WES studies $[95,115,161]$. In addition, a study on autism risk genes in probands from the Autism Clinical and Genetic Resources in China (ACGC) identified one maternally and one paternally inherited missense variant of ITPR1 [118], and another variant is found in patients with NDDs [235]. $\mathrm{IP}_{3} \mathrm{R} 1$ has three main domains including a large $\mathrm{N}$-terminal $\mathrm{IP}_{3}$-binding domain, a short $\mathrm{C}$-terminal hydrophobic domain, and an intervening regulatory domain [236] (Figure 2C). The expression of $\mathrm{IP}_{3} \mathrm{R} 1$ is increased during embryogenesis [237]. Moreover, $\mathrm{IP}_{3} \mathrm{R} 1$ is predominately expressed in the nervous system $[238,239]$ and is expressed in a wide range of brain regions including the cerebellum, cerebral cortex, hippocampus, olfactory bulb, globus pallidus, and striatum [238]. It was reported that homozygous $I P_{3} R 1$-deficient mice mostly die during the embryonic stage, and the born mice have severe ataxia and seizures and die at around P21 [240]. $I P_{3} R 1^{+/-}$mice also show deficits in motor coordination [90] (Table 2; Supplementary Table S1). To study the neural function of $\mathrm{IP}_{3} \mathrm{R} 1$, several $I P_{3} R 1$ brain cKO mouse lines have been generated. A study reported that $L 7$-Cre;Itpr $\mathrm{f}^{\text {flox/flox }}$ mice, in which Itpr1 is deleted in Purkinje cells, exhibit cerebellar ataxia at around 6 weeks and severe ataxia at 8 weeks after birth [91] (Table 2; Supplementary Table S1). L7-Cre;Itpr $1^{\text {flox/flox }}$ mice could survive to adulthood, but display abnormal motor learning ability [91] (Table 2; Supplementary Table S1). In another study, three cKO lines were used, in which Itpr1 deletion was restricted to the cerebral cortex and hippocampus (Emx1-Cre;Itpr $1^{\text {flox/flox }}$ mice), the cerebellum and brainstem (Wnt1-Cre;Itpr $1^{\text {flox/flox }}$ mice), and the caudate putamen and globus pallidus (Gpr88-Cre;Itpr flox/flox $^{\text {flo }}$ mice) [92]. The Emx1-Cre;Itpr $1^{\text {flox/flox }}$ mice and Gpr88-Cre;Itpr $1^{\text {flox/flox }}$ mice were born normally and showed normal growth patterns until adulthood, without apparent dyskinesia like total Itpr I- $^{- \text {mice. }}$ 
However, Wnt1-Cre;Itpr $1^{\text {flox/flox }}$ mice began to show ataxia at around P9, and exhibited dyskinesia from 2 weeks after birth [92] (Table 2; Supplementary Table S1). Wnt1-Cre;Itpr1 $1^{\text {flox/flox }}$ mice show abnormal cerebellar Purkinje cell (PC) firing patterns, due to altered PC activity [92]. Itpr1 deficiency induces a series of abnormal electrophysiological features, including failed LTD in the PCs [241], and excessive LTP induction, attenuated depotentiation and LTP suppression, and altered presynaptic activity in hippocampal CA1 neurons [242,243]. However, typical ASD-related behaviors such as social and repetitive behaviors have not been investigated using these mice.

As enhanced PC activity and dystonia were observed in Wht1-Cre;Itpr $1^{\text {floxfllox }}$ mice, pharmacological inactivation of cerebellar activity by AMPA receptor antagonist (CNQX) infusion was examined for therapeutic effects. Indeed, CNQX ameliorates the dyskinesia in these mice [92] (Table 3). Furthermore, dystonic movements were completely absent in Wnt1-Cre;Itpr $1^{\text {flox/flox }}$ mice with genetic deletion of cerebellar PCs, achieved by mating Wnt1-Cre; Itpr $1^{\text {floxfllox }}$ mice with Lurcher mice $\left(G l u D 2^{\mathrm{LC} /+}\right)$ to kill most of PCs by a mutation of the delta 2 glutamate receptor (GluD2) [92] (Table 3).

\subsection{PRKCA (SFARI Gene Score: 3, Suggestive Evidence)}

Protein kinase $\mathrm{C}$ alpha (PKC- $\alpha$ ) is a member of lipid-sensitive serine/threonine protein kinases that regulate various cellular functions including proliferation, migration, adhesion, differentiation, and apoptosis. PKC- $\alpha$ appears to be a common downstream effector of RhoA, Cdc42, Rac1. PRKCA is located on chromosome 17q24.2. In two WES studies, three de novo missense variants in PRKCA were reported in ASD probands $[95,161]$. PKC- $\alpha$ has a variable regulatory domain at the N-terminus consisting of a $\mathrm{C} 1$ domain and a $\mathrm{C} 2$ domain, which function as the binding sites of diacylglycerol (DAG) and $\mathrm{Ca}^{2+}$, respectively. PKC- $\alpha$ also has a highly conserved kinase domain at the C-terminus comprised by a smaller ATP-binding loop and a substrate-binding site [244,245] (Figure 2C). PKC- $\alpha$ is ubiquitously expressed in all tissues, including the heart, adrenal gland, testis, lung, kidney, spleen, and liver, and is also widespread in various regions of the brain [246]. PKC- $\alpha$ is enriched in both neuronal and glial cultured cells [246]. A PKC- $\alpha$ KO mouse line has been generated, which appears to be normal with regard to external characteristics, viability, and fertility [247]. However, ASD-related behavioral analysis of these mice has not been reported.

\subsection{WASF1 (SFARI Gene Score: S, Syndromic)}

The Rac1 effector WAS protein family member 1 (WASF1), also known as WAVE-1/Scar1, is a member of the WASP-family. WASF1 is located on chromosome 6q21. Using exome sequencing and whole-genome sequencing, three de novo truncated mutations of WASF1 were reported in five unrelated individuals, all of whom presented ID with autistic features and seizures [248]. This is the only study so far that has reported the relationship between WASF1 and ASD. WAVE-1 is composed by a Scar homology domain, a basic domain, a proline-rich region, a WASF homology (WH) domain, and an acidic domain [249] (Figure 2C). In human tissues, the expression of WAVE-1 is restricted to the brain [250]. Mouse study reveals that WAVE-1 shows high expression in the hippocampus, cortex, hypothalamus, amygdala, and cerebellum [93,251,252]. Two mouse lines of homozygous Wave1 deletion are reported to be either postnatal lethal [251] or reduced in body size of offspring [93]. Behavioral analysis using Wave1 KO mice (WAVE-1 null mice) generated by the second strategy showed hypoactivity, impaired motor coordination and balance, reduced anxiety levels, and defected spatial, nonspatial, and emotional learning and memory in the mice [93] (Table 2; Supplementary Table S1).

\section{Conclusions}

In this review, we summarize the findings of 20 ASD-risk genes of Rho GTPase regulators and effectors mainly from their mouse models. Most of these 20 genes are highly expressed in the hippocampus, cortex, amygdala and cerebellum in adult brains. These brain regions are important for behaviors such as social interaction and emotional regulation, and evidence from neuroimaging studies shows altered activation patterns in these regions in ASD individuals [253]. Therefore, mutations 
of Rho GTPase regulators and effectors may cause impaired neural function in these brain regions and thus abnormal behaviors in ASD individuals. Regarding cellular function, 13 of these genes (Arhgef9, Trio, Prex1, Dock1, Dock4, Myo9b, Ophn1, Arhgef32, SrGAP3, Cyfip1, Pak2, Itpr1, and Wave1) play important roles in regulating neuronal development and function, including axon guidance, dendrite and spine morphogenesis, and synaptic plasticity $[60,67,68,71,80,89,92,135,140,150,224,251]$. On the other hand, Dock8 and Myo9b are highly expressed in immune cells. In the nervous system, Dock8 regulates microglia migration [121] and Myo9b may have special function in microglia and astrocytes. It supports the view that microglia and astrocytes modulate synaptic function and contribute to the pathophysiologies of ASD [254,255].

In particular, this review summarizes the recent advances of behavioral and biological phenotypes observed using genetic mouse models of these genes. Most of these 20 genes have mouse models, and multiple behavioral paradigms have been tested in 13 mouse model lines. Notably, seven of these 13 mouse model lines (Trio cKO, Prex1 KO, Dock4 KO, Arhgef10 KO, Ophn1 KO, Argap32 KO, and Pak2 HET mice) exhibit impaired social behaviors and/or repetitive behaviors (Table 2; Supplementary Table S1), which are the core ASD symptoms. Some mouse models, such as Arhgef9 KO mice and Wave1 KO mice, were generated before the genes were found to be related to ASD, therefore ASD-related behavior analyses have not been done in these mouse models and will need to be investigated. Moreover, for some genes, such as DOCK1, ARHGEF5, and NCKAP1, homozygous KO mice are lethal due to severe developmental failure, so their roles in neuronal function and behaviors have not been explored in vivo. For some genes, such as DOCK8 and $M Y O 9 b$, genetic models have not been studied. Besides core symptoms of ASD, other closely related behavioral defects, presented in ASD-comorbid psychiatric disorders such as ID, ADHD, SCZ, are commonly observed in 13 mouse model lines. These include altered anxiety levels and poor learning and memory ability (Table 2; Supplementary Table S1). Findings from these mouse models contribute substantially to the understanding of Rho family GTPase-involved molecular pathogenesis of ASD.

Eight of the abovementioned 13 mouse model lines show synaptic transmission dysfunctions in hippocampal neurons, but the changes vary in different models. Some of the changes may be attributable to the common alteration of a particular Rho GTPase function. For instance, LTP is decreased upon deficiency of the Rac1 GEF Dock4 (Dock4 KO mice) and the Rac1 effector Pak2 (Pak2 HET mice), but is increased when the RhoA effector $\mathrm{IP}_{3} \mathrm{R} 1$ is deleted (Itpr1 KO mice). Moreover, Arhgefg $\mathrm{KO}$ and Prex1 KO mice, leading to inhibited Cdc42 and Rac1, respectively, fail to induce LTD. Arhgefg $\mathrm{KO}$ mice also show decreased GABAergic synaptic function, which is oppositely enhanced in the Rac1 effector Cyfip1 cKO mice. These findings are consistent with the notion that RhoA and Rac1/Cdc42 may play opposite roles in modulating synaptic function. However, many factors, such as Ophn1 and Cyfip1, have additional functions besides participating Rho GTPase pathways. Altered activity of single Rho GTPase may not simply account for all the abnormalities in these mice. Nonetheless, these findings demonstrate that dysfunctions of Rho GTPase regulators and effectors lead to either too much or too little neurotransmission, supporting the hypothesis that impaired excitatory/inhibitory synaptic balance may be one of the pathogenic mechanisms generating ASD-like behaviors.

To investigate the possibility of treating the phenotypes in ASD mouse models, various strategies have been tried, which include genetic manipulation, cellular therapy, pharmacological intervention, and environmental stimulation [256]. We summarize the current successful treatments for mouse models of Rho GTPase regulators and effectors, including pharmacological and non-pharmacological approaches (Table 3). Interestingly, some strategies show similar therapeutic effects in different mouse models. For example, Dock $4 \mathrm{KO}$ and Prex $1^{---}$mice both have reduced hippocampal Rac1 activity and show disruptive NMDA receptor function and social defects. Therefore, similar therapeutic strategies, including drug treatment to restore NMDA receptor function or replenishing Rac1 activity, rescue the defects in neural function and behaviors in both mice. In another case, both Trio cKO and Ophn1 KO mice show increased PKA activity in the cortex, and the abnormal phenotypes due to Trio or Ophn1 deficiency can be restored by the PKA inhibitor Rp-cAMPS treatment. Moreover, a dual inhibitor of 
PKA and ROCK, fasudil, also has therapeutic effects to treat the behavioral defects in Ophn1-1y mice. Other strategies, such as GABA receptor agonist, AMPA receptor antagonist, and mGluR inhibitors, show treatment effects in different individual mice models. These lines of evidence suggest that personalized therapy, through either single or multiple therapeutic strategies, could be possible for patients who share common or unique pathologies due to their genetic variations.

Supplementary Materials: The following are available online at http://www.mdpi.com/2073-4409/9/4/835/s1, Table S1: Summary of ASD-related behavior tests in Rho GEF, GAP, and effector mouse models.

Author Contributions: Conceptualization, L.S. and D.G.; writing-original draft preparation, D.G.; writing - review and editing, D.G., X.Y. and L.S. All authors have read and agreed to the published version of the manuscript.

Funding: This work was supported by The Academy of Medical Sciences Newton Advanced Fellowship in partnership with The Royal Society and The National Natural Science Foundation of China [UK/China grant numbers: AOMS-NAF0051003/81761130084], Key Realm R\&D Program of Guangdong Province (2019B030335001), Local Innovative and Research Teams Project of Guangdong Pearl River Talents Program (2017BT01Y036).

Conflicts of Interest: The authors declare no conflict of interest.

\section{Appendix A}

The order of genes discussed in the review is according to SFARI Gene scores which reflect the gene linkage strengths to ASD; Genes of same score are listed alphabetically.

\section{References}

1. Elsabbagh, M.; Divan, G.; Koh, Y.-J.; Kim, Y.S.; Kauchali, S.; Marcin, C.; Montiel-Nava, C.; Patel, V.; Paula, C.S.; Wang, C.; et al. Global Prevalence of Autism and Other Pervasive Developmental Disorders. Autism Res. 2012, 5, 160-179. [CrossRef] [PubMed]

2. Baron-Cohen, S.; Gullon-Scott, F.; Allison, C.; Williams, J.; Bolton, P.; E Matthews, F.; Brayne, C. Prevalence of autism-spectrum conditions: UK school-based population study. Br. J. Psychiatry 2009, 194, 500-509. [CrossRef] [PubMed]

3. Kim, Y.S.; Leventhal, B.L.; Koh, Y.-J; Fombonne, E.; Laska, E.; Lim, E.-C.; Cheon, K.-A.; Kim, S.-J.; Kim, Y.-K.; Lee, H.; et al. Prevalence of Autism Spectrum Disorders in a Total Population Sample. Am. J. Psychiatry 2011, 168, 904-912. [CrossRef] [PubMed]

4. Kočovská, E.; Biskupstø, R.; Gillberg, I.C.; Ellefsen, A.; Kampmann, H.; Stóra, T.; Billstedt, E.; Gillberg, C. The Rising Prevalence of Autism: A Prospective Longitudinal Study in the Faroe Islands. J. Autism Dev. Disord. 2012, 42, 1959-1966. [CrossRef]

5. Sun, X.; Allison, C.; E Matthews, F.; Sharp, S.; Auyeung, B.; Baron-Cohen, S.; Brayne, C. Prevalence of autism in mainland China, Hong Kong and Taiwan: a systematic review and meta-analysis. Mol. Autism 2013, 4, 7. [CrossRef]

6. Wan, Y.; Hu, Q.; Li, T.; Jiang, L.; Du, Y.; Feng, L.; Wong, J.C.-M.; Li, C.-B. Prevalence of autism spectrum disorders among children in China: a systematic review. Shanghai Arch. Psychiatry 2013, 25, 70-80. [PubMed]

7. Baio, J.; Wiggins, L.; Christence, D.L.; Maenner, M.J.; Daniels, J.; Warren, Z.; Kurzius-Spencer, M.; Zahorodny, W.; Rosenberg, C.R.; White, T.; et al. Prevalence of Autism Spectrum Disorder Among Children Aged 8 Years-Autism and Developmental Disabilities Monitoring Network, 11 Sites, United States, 2014. MMWR Surveill. Summ. 2018, 67, 1-23. [CrossRef]

8. Lai, M.C.; Kassee, C.; Besney, R.; Bonato, S.; Hull, L.; Mandy, W.; Szatmari, P.; Ameis, S.H. Prevalence of co-occurring mental health diagnoses in the autism population: A systematic review and meta-analysis. Lancet Psychiatry 2019, 6, 819-829. [CrossRef]

9. Colvert, E.; Tick, B.; McEwen, F.; Stewart, C.; Curran, S.R.; Woodhouse, E.L.; Gillan, N.; Hallett, V.; Lietz, S.; Garnett, T.; et al. Heritability of Autism Spectrum Disorder in a UK Population-Based Twin Sample. JAMA Psychiatry 2015, 72, 415-423. [CrossRef]

10. Tick, B.; Bolton, P.; Happé, F.; Rutter, M.L.; Rijsdijk, F. Heritability of autism spectrum disorders: A meta-analysis of twin studies. J. Child Psychol. Psychiatry 2015, 57, 585-595. [CrossRef] 
11. Banerjee-Basu, S.; Packer, A. SFARI Gene: An evolving database for the autism research community. Dis. Model. Mech. 2010, 3, 133-135. [CrossRef] [PubMed]

12. Abrahams, B.S.; Arking, D.E.; Campbell, D.; Mefford, H.C.; Morrow, E.M.; Weiss, L.A.; Menashe, I.; Wadkins, T.; Banerjee-Basu, S.; Packer, A. SFARI Gene 2.0: A community-driven knowledgebase for the autism spectrum disorders (ASDs). Mol. Autism 2013, 4, 36. [CrossRef] [PubMed]

13. Basu, S.N.; Kollu, R.; Banerjee-Basu, S. AutDB: A gene reference resource for autism research. Nucleic Acids Res. 2008, 37, D832-D836. [CrossRef] [PubMed]

14. SFARI Gene. Available online: www.sfari.org/resource/sfari-gene/ (accessed on 27 March 2020).

15. AutDB. Available online: http://autism.mindspec.org/autdb/Welcome.do (accessed on 27 March 2020).

16. Ebert, D.H.; Greenberg, M.E. Activity-dependent neuronal signalling and autism spectrum disorder. Nature 2013, 493, 327-337. [CrossRef] [PubMed]

17. Bourgeron, T. From the genetic architecture to synaptic plasticity in autism spectrum disorder. Nat. Rev. Neurosci. 2015, 16, 551-563. [CrossRef] [PubMed]

18. Joensuu, M.; LaNoue, V.; Hotulainen, P. Dendritic spine actin cytoskeleton in autism spectrum disorder. Prog. Neuro-Psychopharmacol. Biol. Psychiatry 2018, 84 Pt B, 362-381. [CrossRef]

19. Tolias, K.F.; Duman, J.; Um, K. Control of synapse development and plasticity by Rho GTPase regulatory proteins. Prog. Neurobiol. 2011, 94, 133-148. [CrossRef]

20. Govek, E.-E.; Newey, S.E.; Van Aelst, L. The role of the Rho GTPases in neuronal development. Genome Res. 2005, 19, 1-49. [CrossRef]

21. Heasman, S.J.; Ridley, A.J. Mammalian Rho GTPases: new insights into their functions from in vivo studies. Nat. Rev. Mol. Cell Biol. 2008, 9, 690-701. [CrossRef]

22. Hodge, R.G.; Ridley, A.J. Regulating Rho GTPases and their regulators. Nat. Rev. Mol. Cell Boil. 2016, 17, 496-510. [CrossRef]

23. Bai, Y.; Xiang, X.; Liang, C.; Shi, L. Regulating Rac in the Nervous System: Molecular Function and Disease Implication of Rac GEFs and GAPs. BioMed. Res. Int. 2015, 2015, 632450. [CrossRef] [PubMed]

24. Fort, P.; Blangy, A. The Evolutionary Landscape of Dbl-Like RhoGEF Families: Adapting Eukaryotic Cells to Environmental Signals. Genome Biol. Evol. 2017, 9, 1471-1486. [CrossRef] [PubMed]

25. Rossman, K.L.; Der, C.J.; Sondek, J. GEF means go: Turning on RHO GTPases with guanine nucleotide-exchange factors. Nat. Rev. Mol. Cell Biol. 2005, 6, 167-180. [CrossRef] [PubMed]

26. Amin, E.; Jaiswal, M.; Derewenda, U.; Reis, K.; Nouri, K.; Koessmeier, K.T.; Aspenström, P.; Somlyo, A.V.; Dvorsky, R.; Ahmadian, M.R. Deciphering the Molecular and Functional Basis of RHOGAP Family Proteins. J. Biol. Chem. 2016, 291, 20353-20371. [CrossRef] [PubMed]

27. Bustelo, X.R.; Sauzeau, V.; Berenjeno, I.M. GTP-binding proteins of the Rho/Rac family: Regulation, effectors and functions in vivo. BioEssays 2007, 29, 356-370. [CrossRef] [PubMed]

28. Shi, L. Dock protein family in brain development and neurological disease. Commun. Integr. Biol. 2013, 6, e26839. [CrossRef] [PubMed]

29. Aguilar, B.J.; Zhu, Y.; Lu, Q. Rho GTPases as therapeutic targets in Alzheimer's disease. Alzheimer's Res. Ther. 2017, 9, 97. [CrossRef]

30. Huang, G.-H.; Sun, Z.-L.; Li, H.-J.; Feng, D.-F. Rho GTPase-activating proteins: Regulators of Rho GTPase activity in neuronal development and CNS diseases. Mol. Cell. Neurosci. 2017, 80, 18-31. [CrossRef]

31. Zamboni, V.; Jones, R.; Umbach, A.; Ammoni, A.; Passafaro, M.; Hirsch, E.; Merlo, G. Rho GTPases in Intellectual Disability: From Genetics to Therapeutic Opportunities. Int. J. Mol. Sci. 2018, 19, 1821. [CrossRef]

32. Niftullayev, S.; Lamarche-Vane, N. Regulators of Rho GTPases in the Nervous System: Molecular Implication in Axon Guidance and Neurological Disorders. Int. J. Mol. Sci. 2019, 20, 1497. [CrossRef]

33. Stankiewicz, T.R.; Linseman, D.A. Rho family GTPases: key players in neuronal development, neuronal survival, and neurodegeneration. Front. Cell. Neurosci. 2014, 8, 314. [CrossRef]

34. Edwards, D.C.; Sanders, L.C.; Bokoch, G.M.; Gill, G.N. Activation of LIM-kinase by Pak1 couples Rac/Cdc42 GTPase signalling to actin cytoskeletal dynamics. Nat. Cell Biol. 1999, 1, 253-259. [CrossRef] [PubMed]

35. Tahirovic, S.; Hellal, F.; Neukirchen, R.; Hindges, R.; Garvalov, B.K.; Flynn, K.C.; Stradal, T.; Chrostek-Grashoff, A.; Brakebusch, C.; Bradke, F. Rac1 Regulates Neuronal Polarization through the WAVE Complex. J. Neurosci. 2010, 30, 6930-6943. [CrossRef] [PubMed]

36. Kang, J.; Park, H.; Kim, E. IRSp53/BAIAP2 in dendritic spine development, NMDA receptor regulation, and psychiatric disorders. Neuropharmacology 2016, 100, 27-39. [CrossRef] [PubMed] 
37. Mpey, S.; Davare, M.; Lasiek, A.; Fortin, D.; Ando, H.; Varlamova, O.; Obrietan, K.; Soderling, T.R.; Goodman, R.H.; Wayman, G.A. An activity-induced microRNA controls dendritic spine formation by regulating Rac1-PAK signaling. Mol. Cell. Neurosci. 2009, 43, 146-156.

38. Reijnders, M.R.; Ansor, N.M.; Kousi, M.; Yue, W.W.; Tan, P.L.; Clarkson, K.; Clayton-Smith, J.; Corning, K.; Jones, J.R.; Lam, W.W.; et al. RAC1 Missense Mutations in Developmental Disorders with Diverse Phenotypes. Am. J. Hum. Genet. 2017, 101, 466-477. [CrossRef]

39. Bolis, A.; Corbetta, S.; Cioce, A.; De Curtis, I. Differential distribution of Rac1 and Rac3 GTPases in the developing mouse brain: implications for a role of Rac3 in Purkinje cell differentiation. Eur. J. Neurosci. 2003, 18, 2417-2424. [CrossRef]

40. Tanabe, K.; Tachibana, T.; Yamashita, T.; Che, Y.H.; Yoneda, Y.; Ochi, T.; Tohyama, M.; Yoshikawa, H.; Kiyama, H. The Small GTP-Binding Protein TC10 Promotes Nerve Elongation in Neuronal Cells, and Its Expression Is induced during Nerve Regeneration in Rats. J. Neurosci. 2000, 20, 4138-4144. [CrossRef]

41. Corbetta, S.; Gualdoni, S.; Albertinazzi, C.; Paris, S.; Croci, L.; Consalez, G.G.; De Curtis, I. Generation and Characterization of Rac3 Knockout Mice. Mol. Cell. Biol. 2005, 25, 5763-5776. [CrossRef]

42. Sugihara, K.; Nakatsuji, N.; Nakamura, K.; Nakao, K.; Hashimoto, R.; Otani, H.; Sakagami, H.; Kondo, H.; Nozawa, S.; Aiba, A.; et al. Rac1 is required for the formation of three germ layers during gastrulation. Oncogene 1998, 17, 3427-3433. [CrossRef]

43. Chen, L.; Liao, G.; Waclaw, R.R.; Burns, K.A.; Linquist, D.; Campbell, K.; Zheng, Y.; Kuan, C.-Y. Rac1 Controls the Formation of Midline Commissures and the Competency of Tangential Migration in Ventral Telencephalic Neurons. J. Neurosci. 2007, 27, 3884-3893. [CrossRef] [PubMed]

44. Chen, L.; Melendez, J.; Campbell, K.; Kuan, C.-Y.; Zheng, Y. Rac1 deficiency in the forebrain results in neural progenitor reduction and microcephaly. Dev. Biol. 2009, 325, 162-170. [CrossRef] [PubMed]

45. Hua, Z.L.; Emiliani, F.E.; Nathans, J. Rac1 plays an essential role in axon growth and guidance and in neuronal survival in the central and peripheral nervous systems. Neural Dev. 2015, 10, 21. [CrossRef] [PubMed]

46. Vidaki, M.; Tivodar, S.; Doulgeraki, K.; Tybulewicz, V.L.; Kessaris, N.; Pachnis, V.; Karagogeos, D. Rac1-Dependent Cell Cycle Exit of MGE Precursors and GABAergic Interneuron Migration to the Cortex. Cereb. Cortex 2011, 22, 680-692. [CrossRef] [PubMed]

47. Haditsch, U.; Leone, D.P.; Farinelli, M.; Chrostek-Grashoff, A.; Brakebusch, C.; Mansuy, I.M.; McConnell, S.K.; Palmer, T.D. A central role for the small GTPase Rac1 in hippocampal plasticity and spatial learning and memory. Mol. Cell. Neurosci. 2009, 41, 409-419. [CrossRef] [PubMed]

48. Haditsch, U.; Anderson, M.P.; Freewoman, J.; Cord, B.; Babu, H.; Brakebusch, C.; Palmer, T.D. Neuronal Rac1 is required for learning-evoked neurogenesis. J. Neurosci. 2013, 33, 12229-12241. [CrossRef]

49. Pennucci, R.; Talpo, F.; Astro, V.; Montinaro, V.; Morè, L.; Cursi, M.; Castoldi, V.; Chiaretti, S.; Bianchi, V.; Marenna, S.; et al. Loss of Either Rac1 or Rac3 GTPase Differentially Affects the Behavior of Mutant Mice and the Development of Functional GABAergic Networks. Cereb. Cortex 2016, 26, 873-890. [CrossRef]

50. Viaud, J.; Gaits-Iacovoni, F.; Payrastre, B. Regulation of the DH-PH tandem of guanine nucleotide exchange factor for Rho GTPases by phosphoinositides. Adv. Biol. Regul. 2012, 52, 303-3144. [CrossRef]

51. Lawson, C.D.; Ridley, A.J. Rho GTPase signaling complexes in cell migration and invasion. J. Cell Biol. 2017, 217, 447-457. [CrossRef]

52. Cote, J.F.; Vuori, K. In vitro guanine nucleotide exchange activity of DHR-2/DOCKER/CZH2 domains. Methods Enzymol. 2006, 406, 41-57.

53. Namekata, K.; Kimura, A.; Kawamura, K.; Harada, C.; Harada, T. Dock GEFs and their therapeutic potential: Neuroprotection and axon regeneration. Prog. Retin. Eye Res. 2014, 43, 1-16. [CrossRef] [PubMed]

54. Machado, C.O.F.; Griesi-Oliveira, K.; Rosenberg, C.; Kok, F.; Martins, S.; Passos-Bueno, M.R.; Sertie, A. Collybistin binds and inhibits mTORC1 signaling: A potential novel mechanism contributing to intellectual disability and autism. Eur. J. Hum. Genet. 2015, 24, 59-65. [CrossRef] [PubMed]

55. Bhat, G.; Lagrave, D.; Millson, A.; Herriges, J.; Lamb, A.N.; Matalon, R. Xq11.1-11.2 deletion involving ARHGEF9 in a girl with autism spectrum disorder. Eur. J. Med. Genet. 2016, 59, 470-473. [CrossRef] [PubMed]

56. Alber, M.; Kalscheuer, V.M.; Marco, E.; Sherr, E.; Lesca, G.; Till, M.; Gradek, G.; Wiesener, A.; Korenke, C.; Mercier, S.; et al. ARHGEF9 disease: Phenotype clarification and genotype-phenotype correlation. Neurol. Genet. 2017, 3, e148. [CrossRef] 
57. Aarabi, M.; Infante, E.; Madan-Khetarpal, S.; Surti, U.; Bellissimo, D.; Rajkovic, A.; Yatsenko, S.A. Autism spectrum disorder in females with ARHGEF9 alterations and a random pattern of $\mathrm{X}$ chromosome inactivation. Eur. J. Med. Genet. 2018, 62, 239-242. [CrossRef]

58. Xiong, J.; Chen, S.; Pang, N.; Deng, X.; Yang, L.; He, F.; Wu, L.; Chen, C.; Yin, F.; Peng, J. Neurological Diseases with Autism Spectrum Disorder: Role of ASD Risk Genes. Front. Mol. Neurosci. 2019, 13, 349. [CrossRef]

59. Kins, S.; Betz, H.; Kirsch, J. Collybistin, a newly identified brain-specific GEF, induces submembrane clustering of gephyrin. Nat. Neurosci. 2000, 3, 22-29. [CrossRef]

60. De Groot, C.; Floriou-Servou, A.; Tsai, Y.-C.; Früh, S.; Kohler, M.; Parkin, G.; Schwerdel, C.; Bosshard, G.; Kaila, K.; Fritschy, J.-M.; et al. RhoGEF9 splice isoforms influence neuronal maturation and synapse formation downstream of $\alpha 2$ GABAA receptors. PLoS Genet. 2017, 13, e1007073. [CrossRef]

61. Kneussel, M.; Engelkamp, D.; Betz, H. Distribution of transcripts for the brain-specific GDP/GTP exchange factor collybistin in the developing mouse brain. Eur. J. Neurosci. 2001, 13, 487-492. [CrossRef]

62. Ibaraki, K.; Mizuno, M.; Aoki, H.; Niwa, A.; Iwamoto, I.; Hara, A.; Tabata, H.; Ito, H.; Nagata, K.-I. Biochemical and Morphological Characterization of a Guanine Nucleotide Exchange Factor ARHGEF9 in Mouse Tissues. Acta Histochem. ET Cytochem. 2018, 51, 119-128. [CrossRef]

63. Papadopoulos, T.; Korte, M.; Eulenburg, V.; Kubota, H.; Retiounskaia, M.; Harvey, R.J.; Harvey, K.; O'Sullivan, G.A.; Laube, B.; Hülsmann, S.; et al. Impaired GABAergic transmission and altered hippocampal synaptic plasticity in collybistin-deficient mice. EMBO J. 2007, 26, 3888-3899. [CrossRef] [PubMed]

64. Jedlicka, P.; Papadopoulos, T.; Deller, T.; Betz, H.; Schwarzacher, S.W. Increased network excitability and impaired induction of long-term potentiation in the dentate gyrus of collybistin-deficient mice in vivo. Mol. Cell. Neurosci. 2009, 41, 94-100. [CrossRef] [PubMed]

65. Jedlicka, P.; Muellerleile, J.; Schwarzacher, S.W. Synaptic Plasticity and Excitation-Inhibition Balance in the Dentate Gyrus: Insights fromIn VivoRecordings in Neuroligin-1, Neuroligin-2, and Collybistin Knockouts. Neural Plast. 2018, 2018, 6015753. [CrossRef] [PubMed]

66. Zong, W.; Liu, S.; Wang, X.; Zhang, J.; Zhang, T.; Liu, Z.; Wang, N.; Zhang, A.; Zhu, M.; Gao, J. Trio gene is required for mouse learning ability. Brain Res. 2015, 1608, 82-90. [CrossRef] [PubMed]

67. Katrancha, S.M.; Shaw, J.E.; Zhao, A.Y.; Myers, S.A.; Cocco, A.R.; Jeng, A.T.; Zhu, M.; Pittenger, C.; Greer, C.A.; Carr, S.A.; et al. Trio Haploinsufficiency Causes Neurodevelopmental Disease-Associated Deficits. Cell Rep. 2019, 26, 2805-2817.e9. [CrossRef]

68. Li, J.; Chai, A.; Wang, L.; Ma, Y.; Wu, Z.; Yu, H.; Mei, L.; Lu, L.; Zhang, C.; Yue, W.; et al. Synaptic P-Rex1 signaling regulates hippocampal long-term depression and autism-like social behavior. Proc. Natl. Acad. Sci. USA 2015, 112, E6964-E6972. [CrossRef]

69. Lu, D.-H.; Liao, H.-M.; Chen, C.-H.; Tu, H.-J.; Liou, H.-C.; Gau, S.S.-F.; Fu, W.-M. Impairment of social behaviors in Arhgef10 knockout mice. Mol. Autism 2018, 9, 11. [CrossRef]

70. Guo, D.; Peng, Y.; Wang, L.; Sun, X.; Wang, X.; Liang, C.; Yang, X.; Li, S.; Xu, J.; Ye, W.-C.; et al. Autism-like social deficit generated by Dock 4 deficiency is rescued by restoration of Rac1 activity and NMDA receptor function. Mol. Psychiatry 2019. [CrossRef]

71. Khelfaoui, M.; Denis, C.; van Galen, E.; de Bock, F.; Schmitt, A.; Houbron, C.; Morice, E.; Giros, B.; Ramakers, G.; Fagni, L.; et al. Loss of X-linked mental retardation gene oligophrenin 1 in mice impairs spatial memory and leads to ventricular enlargement and dendritic spine immaturity. J. Neurosci. 2007, 27, 9439-9450. [CrossRef]

72. Meziane, H.; Khelfaoui, M.; Morello, N.; Hiba, B.; Calcagno, E.; Reibel-Foisset, S.; Selloum, M.; Chelly, J.; Humeau, Y.; Riet, F.; et al. Fasudil treatment in adult reverses behavioural changes and brain ventricular enlargement in Oligophrenin-1 mouse model of intellectual disability. Hum. Mol. Genet. 2016, 25, $2314-2323$. [CrossRef]

73. Redolfi, N.; Galla, L.; Maset, A.; Murru, L.; Savoia, E.; Zamparo, I.; Gritti, A.; Billuart, P.; Passafaro, M.; Lodovichi, C. Oligophrenin-1 regulates number, morphology and synaptic properties of adult-born inhibitory interneurons in the olfactory bulb. Hum. Mol. Genet. 2016, 25, 5198-5211. [CrossRef] [PubMed]

74. Khelfaoui, M.; Gambino, F.; Houbaert, X.; Ragazzon, B.; Müller, C.; Carta, M.; Lanore, F.; Srikumar, B.N.; Gastrein, P.; Lepleux, M.; et al. Lack of the presynaptic RhoGAP protein oligophrenin1 leads to cognitive disabilities through dysregulation of the cAMP/PKA signalling pathway. Philos. Trans. R. Soc. Lond. B Biol. Sci. 2013, 369, 20130160. [CrossRef] 
75. Zhang, C.-L.; Aime, M.; Laheranne, E.; Houbaert, X.; El Oussini, H.; Martin, C.; Lepleux, M.; Normand, E.; Chelly, J.; Herzog, E.; et al. Protein Kinase A Deregulation in the Medial Prefrontal Cortex Impairs Working Memory in Murine Oligophrenin-1 Deficiency. J. Neurosci. 2017, 37, 11114-11126. [CrossRef] [PubMed]

76. Nakamura, T.; Arima-Yoshida, F.; Sakaue, F.; Nasu-Nishimura, Y.; Takeda, Y.; Matsuura, K.; Akshoomoff, N.; Mattson, S.N.; Grossfeld, P.D.; Manabe, T.; et al. PX-RICS-deficient mice mimic autism spectrum disorder in Jacobsen syndrome through impaired GABAA receptor trafficking. Nat. Commun. 2016, 7, 10861. [CrossRef] [PubMed]

77. Nakamura, T.; Sakaue, F.; Nasu-Nishimura, Y.; Takeda, Y.; Matsuura, K.; Akiyama, T. The Autism-Related Protein PX-RICS Mediates GABAergic Synaptic Plasticity in Hippocampal Neurons and Emotional Learning in Mice. Ebiomedicine 2018, 34, 189-200. [CrossRef] [PubMed]

78. Carlson, B.R.; Lloyd, K.E.; Kruszewski, A.; Kim, I.-H.; Rodriguiz, R.M.; Heindel, C.; Faytell, M.; Dudek, S.M.; Wetsel, W.C.; Soderling, S.H. WRP/srGAP3 Facilitates the Initiation of Spine Development by an Inverse F-BAR Domain, and Its Loss Impairs Long-Term Memory. J. Neurosci. 2011, 31, 2447-2460. [CrossRef] [PubMed]

79. Waltereit, R.; Leimer, U.; Halbach, O.v.B.U.; Panke, J.; Hoelter, S.M.; Garrett, L.; Wittig, K.; Schneider, M.; Schmitt, C.; Calzada-Wack, J.; et al. Srgap3(-/-) mice present a neurodevelopmental disorder with schizophrenia-related intermediate phenotypes. FASEB J. 2012, 26, 4418-4428. [CrossRef] [PubMed]

80. Bertram, J.; Koschuetzke, L.; Pfannmoeller, J.P.; Esche, J.; van Diepen, L.; Kuss, A.W.; Hartmann, B.; Bartsch, D.; Lotze, M.; van Halbach, O.B.U. Morphological and behavioral characterization of adult mice deficient for SrGAP3. Cell Tissue Res. 2016, 366, 1-11. [CrossRef] [PubMed]

81. Janne, P.A.; Suchy, S.F.; Bernard, D.; MacDonald, M.; Crawley, J.; Grinberg, A.; Wynshaw-Boris, A.; Westphal, H.; Nussbaum, R.L. Functional overlap between murine Inpp5b and Ocrl1 may explain why deficiency of the murine ortholog for OCRL1 does not cause Lowe syndrome in mice. J. Clin. Investig 1998, 101, 2042-2053. [CrossRef]

82. Festa, B.P.; Berquez, M.; Gassama, A.; Amrein, I.; Ismail, H.M.; Samardzija, M.; Staiano, L.; Luciani, A.; Grimm, C.; Nussbaum, R.L.; et al. OCRL deficiency impairs endolysosomal function in a humanized mouse model for Lowe syndrome and Dent disease. Hum. Mol. Genet. 2019, 28, 1931-1946. [CrossRef]

83. Bozdagi, O.; Sakurai, T.; Dorr, N.; Pilorge, M.; Takahashi, N.; Buxbaum, J.D. Haploinsufficiency of Cyfip1 produces fragile X-like phenotypes in mice. PLoS ONE 2012, 7, e42422. [CrossRef] [PubMed]

84. Bachmann, S.O.; Sledziowska, M.; Cross, E.; Kalbassi, S.; Waldron, S.; Chen, F.; Ranson, A.; Baudouin, S.J. Behavioral training rescues motor deficits in Cyfip1 haploinsufficiency mouse model of autism spectrum disorders. Transl. Psychiatry 2019, 9, 29. [CrossRef] [PubMed]

85. Chung, L.; Wang, X.; Zhu, L.; Towers, A.J.; Cao, X.; Kim, I.H.; Jiang, Y.-H. Parental origin impairment of synaptic functions and behaviors in cytoplasmic FMRP interacting protein 1 (Cyfip1) deficient mice. Brain Res. 2015, 1629, 340-350. [CrossRef] [PubMed]

86. Domínguez-Iturza, N.; Lo, A.C.; Shah, D.; Armendáriz, M.; Vannelli, A.; Mercaldo, V.; Trusel, M.; Li, K.W.; Gastaldo, D.; Santos, A.R.; et al. The autism- and schizophrenia-associated protein CYFIP1 regulates bilateral brain connectivity and behaviour. Nat. Commun. 2019, 10, 3454. [CrossRef] [PubMed]

87. Silva, A.I.; Haddon, J.E.; Ahmed Syed, Y.; Trent, S.; Lin, T.-C.E.; Patel, Y.; Carter, J.; Haan, N.; Honey, R.C.; Humby, T.; et al. Cyfip1 haploinsufficient rats show white matter changes, myelin thinning, abnormal oligodendrocytes and behavioural inflexibility. Nat. Commun. 2019, 10, 3455. [CrossRef]

88. Fricano-Kugler, C.; Gordon, A.; Shin, G.; Gao, K.; Nguyen, J.; Berg, J.; Starks, M.; Geschwind, D.H. CYFIP1 overexpression increases fear response in mice but does not affect social or repetitive behavioral phenotypes. Mol. Autism 2019, 10, 25. [CrossRef]

89. Wang, Y.; Zeng, C.; Li, J.; Zhou, Z.; Ju, X.; Xia, S.; Li, Y.; Liu, A.; Teng, H.; Zhang, K.; et al. PAK2 Haploinsufficiency Results in Synaptic Cytoskeleton Impairment and Autism-Related Behavior. Cell Rep. 2018, 24, 2029-2041. [CrossRef]

90. Ogura, H.; Matsumoto, M.; Mikoshiba, K. Motor discoordination in mutant mice heterozygous for the type 1 inositol 1,4,5-trisphosphate receptor. Behav. Brain Res. 2001, 122, 215-219. [CrossRef]

91. Sugawara, T.; Hisatsune, C.; Le, T.D.; Hashikawa, T.; Hirono, M.; Hattori, M.; Nagao, S.; Mikoshiba, K. Type 1 Inositol Trisphosphate Receptor Regulates Cerebellar Circuits by Maintaining the Spine Morphology of Purkinje Cells in Adult Mice. J. Neurosci. 2013, 33, 12186. [CrossRef] 
92. Hisatsune, C.; Miyamoto, H.; Hirono, M.; Yamaguchi, N.; Sugawara, T.; Ogawa, N.; Ebisui, E.; Ohshima, T.; Yamada, M.; Hensch, T.K.; et al. IP3R1 deficiency in the cerebellum/brainstem causes basal ganglia-independent dystonia by triggering tonic Purkinje cell firings in mice. Front. Neural Circuits 2013, 7, 156. [CrossRef]

93. Soderling, S.H.; Langeberg, L.K.; Soderling, J.A.; Davee, S.M.; Simerly, R.; Raber, J.; Scott, J.D. Loss of WAVE-1 causes sensorimotor retardation and reduced learning and memory in mice. Proc. Natl. Acad. Sci. USA 2003, 100, 1723-1728. [CrossRef] [PubMed]

94. Ren, J.; Wen, L.; Gao, X.; Jin, C.; Xue, Y.; Yao, X. DOG 1.0: illustrator of protein domain structures. Cell Res. 2009, 19, 271-273. [CrossRef] [PubMed]

95. De Rubeis, S.; He, X.; Goldberg, A.P.; Poultney, C.S.; E Samocha, K.; Cicek, A.E.; Kou, Y.; Liu, L.; Fromer, M.; Singh, T.; et al. Synaptic, transcriptional and chromatin genes disrupted in autism. Nature 2014, 515, 209-215. [CrossRef] [PubMed]

96. Turner, T.N.; Hormozdiari, F.; Duyzend, M.; McClymont, S.A.; Hook, P.W.; Iossifov, I.; Raja, A.; Baker, C.; Hoekzema, K.; Stessman, H.A.; et al. Genome Sequencing of Autism-Affected Families Reveals Disruption of Putative Noncoding Regulatory DNA. Am. J. Hum. Genet. 2016, 98, 58-74. [CrossRef]

97. Takata, A.; Miyake, N.; Tsurusaki, Y.; Fukai, R.; Miyatake, S.; Koshimizu, E.; Kushima, I.; Okada, T.; Morikawa, M.; Uno, Y.; et al. Integrative Analyses of De Novo Mutations Provide Deeper Biological Insights into Autism Spectrum Disorder. Cell Rep. 2018, 22, 734-747. [CrossRef]

98. Stessman, H.; Xiong, B.; Coe, B.P.; Wang, T.; Hoekzema, K.; Fenckova, M.; Kvarnung, M.; Gerdts, J.; Trinh, S.; Cosemans, N.; et al. Targeted sequencing identifies 91 neurodevelopmental-disorder risk genes with autism and developmental-disability biases. Nat. Genet. 2017, 49, 515-526. [CrossRef]

99. Aspromonte, M.C.; Bellini, M.; Gasparini, A.; Carraro, M.; Bettella, E.; Polli, R.; Cesca, F.; Bigoni, S.; Carlet, O.; Negrin, S.; et al. Characterization of intellectual disability and autism comorbidity through gene panel sequencing. Hum. Mutat. 2019, 40, 1346-1363. [CrossRef]

100. Sadybekov, A.; Tian, C.; Arnesano, C.; Katritch, V.; Herring, B.E. An autism spectrum disorder-related de novo mutation hotspot discovered in the GEF1 domain of Trio. Nat. Commun. 2017, 8, 601. [CrossRef]

101. Barbosa, S.; Greville-Heygate, S.; Bonnet, M.; Godwin, A.; Fagotto-Kaufmann, C.; Kajava, A.V.; Laouteouet, D.; Mawby, R.; Wai, H.A.; Dingemans, A.J.; et al. Opposite Modulation of RAC1 by Mutations in TRIO Is Associated with Distinct, Domain-Specific Neurodevelopmental Disorders. Am. J. Hum. Genet. 2020, 106, 338-355. [CrossRef]

102. Schmidt, S.; Debant, A. Function and regulation of the Rho guanine nucleotide exchange factor Trio. Small GTPases 2014, 5, e29769. [CrossRef]

103. Medley, Q.G.; Serra-Pagès, C.; Iannotti, E.; Seipel, K.; Tang, M.; O’Brien, S.; Streuli, M. The Trio Guanine Nucleotide Exchange Factor Is a RhoA Target. J. Biol. Chem. 2000, 275, 36116-36123. [CrossRef] [PubMed]

104. McPherson, C.E.; Eipper, B.A.; Mains, R.E. Multiple novel isoforms of Trio are expressed in the developing rat brain. Gene 2005, 347, 125-135. [CrossRef]

105. Portales-Casamar, E.; Briançon-Marjollet, A.; Fromont, S.; Triboulet, R.; Debant, A. Identification of novel neuronal isoforms of the Rho-GEF Trio. Biol. Cell 2006, 98, 183-193. [CrossRef] [PubMed]

106. O’Brien, S.P.; Seipel, K.; Medley, Q.G.; Bronson, R.; Segal, R.; Streuli, M. Skeletal muscle deformity and neuronal disorder in Trio exchange factor-deficient mouse embryos. Proc. Natl. Acad. Sci. USA 2000, 97, 12074-12078. [CrossRef] [PubMed]

107. Peng, Y.-J.; He, W.-Q.; Tang, J.; Tao, T.; Chen, C.; Gao, Y.-Q.; Zhang, W.-C.; He, X.; Dai, Y.-Y.; Zhu, N.-C.; et al. Trio Is a Key Guanine Nucleotide Exchange Factor Coordinating Regulation of the Migration and Morphogenesis of Granule Cells in the Developing Cerebellum. J. Biol. Chem. 2010, 285, 24834-24844. [CrossRef]

108. Goebbels, S.; Bormuth, I.; Bode, U.; Hermanson, O.; Schwab, M.H.; Nave, K. Genetic targeting of principal neurons in neocortex and hippocampus of NEX-Cre mice. Genesis 2006, 44, 611-621. [CrossRef]

109. Huang, M.; Liang, C.; Li, S.; Zhang, J.; Guo, D.; Zhao, B.; Liu, Y.; Peng, Y.; Xu, J.; Liu, W.; et al. Two Autism/Dyslexia Linked Variations of DOCK4 Disrupt the Gene Function on Rac1/Rap1 Activation, Neurite Outgrowth, and Synapse Development. Front. Cell. Neurosci. 2020, 13, 577. [CrossRef]

110. Nishikimi, A.; Kukimoto-Niino, M.; Yokoyama, S.; Fukui, Y. Immune regulatory functions of DOCK family proteins in health and disease. Exp. Cell Res. 2013, 319, 2343-2349. [CrossRef] 
111. Harada, Y.; Tanaka, Y.; Terasawa, M.; Pieczyk, M.; Habiro, K.; Katakai, T.; Hanawa-Suetsugu, K.; Kukimoto-Niino, M.; Nishizaki, T.; Shirouzu, M.; et al. DOCK8 is a Cdc42 activator critical for interstitial dendritic cell migration during immune responses. Blood 2012, 119, 4451-4461. [CrossRef]

112. Kunimura, K.; Uruno, T.; Fukui, Y. DOCK family proteins: Key players in immune surveillance mechanisms. Int. Immunol. 2020, 32, 5-15. [CrossRef]

113. Allen-Brady, K.; Miller, J.; Matsunami, N.; Stevens, J.; Block, H.; Farley, M.; Krasny, L.; Pingree, C.; Lainhart, J.; Leppert, M.; et al. A high-density SNP genome-wide linkage scan in a large autism extended pedigree. Mol. Psychiatry 2008, 14, 590-600. [CrossRef] [PubMed]

114. Coon, H.; E Villalobos, M.; Robison, R.J.; Camp, N.J.; Cannon, D.S.; Allen-Brady, K.; Miller, J.S.; McMahon, W.M. Genome-wide linkage using the Social Responsiveness Scale in Utah autism pedigrees. Mol. Autism 2010, 1, 8. [CrossRef] [PubMed]

115. Wang, T.; Guo, H.; Xiong, B.; Stessman, H.A.; Wu, H.; Coe, B.P.; Turner, T.; Liu, Y.; Zhao, W.; Hoekzema, K.; et al. De novo genic mutations among a Chinese autism spectrum disorder cohort. Nat. Commun. 2016, 7, 13316. [CrossRef] [PubMed]

116. Glessner, J.; Li, J.; Wang, D.; March, M.; Lima, L.; Desai, A.; Hadley, D.; Kao, C.; Gur, R.E.; Sleiman, P.M.; et al. Copy number variation meta-analysis reveals a novel duplication at 9p24 associated with multiple neurodevelopmental disorders. Genome Med. 2017, 9, 1-11. [CrossRef]

117. Krgovic, D.; Vokac, N.K.; Zagorac, A.; Kumperscak, H.G. Rare structural variants in the DOCK8 gene identified in a cohort of 439 patients with neurodevelopmental disorders. Sci. Rep. 2018, 8, 9449. [CrossRef]

118. Guo, H.; Wang, T.; Wu, H.; Long, M.; Coe, B.P.; Li, H.; Xun, G.; Ou, J.-J.; Chen, B.; Duan, G.; et al. Inherited and multiple de novo mutations in autism/developmental delay risk genes suggest a multifactorial model. Mol. Autism 2018, 9, 64. [CrossRef]

119. Ruzzo, E.K.; Pérez-Cano, L.; Jung, J.Y.; Wang, L.K.; Kashef-Haghighi, D.; Hartl, C.; Singh, C.; Xu, J.; Hoekstra, J.N.; Leventhal, O.; et al. Inherited and De Novo Genetic Risk for Autism Impacts Shared Networks. Cell 2019, 178, 850-866.e26. [CrossRef]

120. Biggs, C.; Keles, S.; Chatila, T.A. DOCK8 deficiency: Insights into pathophysiology, clinical features and management. Clin. Immunol. 2017, 181, 75-82. [CrossRef]

121. Namekata, K.; Guo, X.; Kimura, A.; Arai, N.; Harada, C.; Harada, T. DOCK8 is expressed in microglia, and it regulates microglial activity during neurodegeneration in murine disease models. J. Biol. Chem. 2019, 294, 13421-13433. [CrossRef]

122. Rynkiewicz, N.; Liu, T.; Balamatsias, D.; Mitchell, C.A. INPP4A/INPP4B and P-Rex proteins: Related but different? Adv. Biol. Regul. 2012, 52, 265-279. [CrossRef]

123. Welch, H. Regulation and function of P-Rex family Rac-GEFs. Small GTPases 2015, 6, 49-70. [CrossRef] [PubMed]

124. Welch, H.C.; Coadwell, W.J.; Ellson, C.D.; Ferguson, G.J.; Andrews, S.R.; Erdjument-Bromage, H.; Tempst, P.; Hawkins, P.T.; Stephens, L.R. P-Rex1, a PtdIns(3,4,5)P-3- and G beta gamma-regulated guanine-nucleotide exchange factor for Rac. Cell 2002, 108, 809-821. [CrossRef]

125. Yoshizawa, M.; Kawauchi, T.; Sone, M.; Nishimura, Y.V.; Terao, M.; Chihama, K.; Nabeshima, Y.-I.; Hoshino, M. Involvement of a Rac Activator, P-Rex1, in Neurotrophin-Derived Signaling and Neuronal Migration. J. Neurosci. 2005, 25, 4406-4419. [CrossRef] [PubMed]

126. Donald, S.; Humby, T.; Fyfe, I.; Segonds-Pichon, A.; Walker, S.; Andrews, S.R.; Coadwell, W.J.; Emson, P.; Wilkinson, L.S.; Welch, H. P-Rex2 regulates Purkinje cell dendrite morphology and motor coordination. Proc. Natl. Acad. Sci. USA 2008, 105, 4483-4488. [CrossRef] [PubMed]

127. Garcia-Mata, R.; Burridge, K. Catching a GEF by its tail. Trends Cell Biol. 2007, 17, 36-43. [CrossRef] [PubMed]

128. Chaya, T.; Shibata, S.; Tokuhara, Y.; Yamaguchi, W.; Matsumoto, H.; Kawahara, I.; Kogo, M.; Ohoka, Y.; Inagaki, S. Identification of a Negative Regulatory Region for the Exchange Activity and Characterization of T332I Mutant of Rho Guanine Nucleotide Exchange Factor 10 (ARHGEF10). J. Biol. Chem. 2011, 286, 29511-29520. [CrossRef]

129. Shibata, S.; Teshima, Y.; Niimi, K.; Inagaki, S. Involvement of ARHGEF10, GEF for RhoA, in Rab6/Rab8-mediating membrane traffic. Small GTPases 2019, 10, 169-177. [CrossRef]

130. Li, J.; Wang, L.; Guo, H.; Shi, L.; Zhang, K.; Tang, M.; Hu, S.; Dong, S.; Liu, C.; Wang, T.; et al. Targeted sequencing and functional analysis reveal brain-size-related genes and their networks in autism spectrum disorders. Mol. Psychiatry 2017, 22, 1282-1290. [CrossRef] 
131. Verhoeven, K.; De Jonghe, P.; Van De Putte, T.; Nelis, E.; Zwijsen, A.; Verpoorten, N.; De Vriendt, E.; Jacobs, A.; Van Gerwen, V.; Francis, A.; et al. Slowed conduction and thin myelination of peripheral nerves associated with mutant Rho guanine-nucleotide exchange factor 10. Am. J. Hum. Genet. 2003, 73, 926-932. [CrossRef]

132. Cote, J.F.; Vuori, K. Identification of an evolutionarily conserved superfamily of DOCK180-related proteins with guanine nucleotide exchange activity. J. Cell Sci. 2002, 115 Pt 24, 4901-4913. [CrossRef]

133. Griswold, A.J.; Dueker, N.D.; Van Booven, D.J.; Rantus, J.A.; Jaworski, J.M.; Slifer, S.H.; Schmidt, M.A.; Hulme, W.; Konidari, I.; Whitehead, P.G.; et al. Targeted massively parallel sequencing of autism spectrum disorder-associated genes in a case control cohort reveals rare loss-of-function risk variants. Mol. Autism 2015, 6, 43. [CrossRef] [PubMed]

134. Coci, E.G.; Auhuber, A.; Langenbach, A.; Mrasek, K.; Riedel, J.; Leenen, A.; Liehr, T.; Lücke, T. Novel Unbalanced Translocations Affecting the Long Arms of Chromosomes 10 and 22 Cause Complex Syndromes with Very Severe Neurodevelopmental Delay, Speech Impairment, Autistic Behavior, and Epilepsy. Cytogenet. Genome Res. 2017, 151, 171-178. [CrossRef] [PubMed]

135. Kim, J.Y.; Oh, M.H.; Bernard, L.P.; Macara, I.G.; Zhang, H. The RhoG/ELMO1/Dock180 signaling module is required for spine morphogenesis in hippocampal neurons. J. Biol. Chem. 2011, 286, 37615-37624. [CrossRef] [PubMed]

136. Laurin, M.; Fradet, N.; Blangy, A.; Hall, A.; Vuori, K.; Coté, J.-F. The atypical Rac activator Dock180 (Dock1) regulates myoblast fusion in vivo. Proc. Natl. Acad. Sci. USA 2008, 105, 15446-15451. [CrossRef]

137. Maestrini, E.; Pagnamenta, A.T.; Lamb, J.; Bacchelli, E.; Sykes, N.H.; De Sousa, I.G.M.; Toma, C.; Barnby, G.; Butler, H.; Winchester, L.; et al. High-density SNP association study and copy number variation analysis of the AUTS1 and AUTS5 loci implicate the IMMP2L-DOCK4 gene region in autism susceptibility. Mol. Psychiatry 2009, 15, 954-968. [CrossRef]

138. Pagnamenta, A.T.; Bacchelli, E.; De Jonge, M.V.; Mirza, G.; Scerri, T.S.; Minopoli, F.; Chiocchetti, A.; Ludwig, K.U.; Hoffmann, P.; Paracchini, S.; et al. Characterization of a Family with Rare Deletions in CNTNAP5 and DOCK4 Suggests Novel Risk Loci for Autism and Dyslexia. Biol. Psychiatry 2010, 68, 320-328. [CrossRef]

139. Liang, S.; Wang, X.-L.; Zou, M.-Y.; Wang, H.; Zhou, X.; Sun, C.-H.; Xia, W.; Wu, L.-J.; Fujisawa, T.X.; Tomoda, A. Family-based association study of ZNF533, DOCK4 and IMMP2L gene polymorphisms linked to autism in a northeastern Chinese Han population. J. Zhejiang Univ. Sci. B 2014, 15, 264-271. [CrossRef]

140. Xiao, Y.; Peng, Y.; Wan, J.; Tang, G.; Chen, Y.; Tang, J.; Ye, W.-C.; Ip, N.Y.; Shi, L. The Atypical Guanine Nucleotide Exchange Factor Dock4 Regulates Neurite Differentiation through Modulation of Rac1 GTPase and Actin Dynamics. J. Biol. Chem. 2013, 288, 20034-20045. [CrossRef]

141. Tcherkezian, J.; Lamarche-Vane, N. Current knowledge of the large RhoGAP family of proteins. Biol. Cell 2007, 99, 67-86. [CrossRef]

142. Reinhard, J.; Scheel, A.; Diekmann, D.; Hall, A.; Ruppert, C.; Bähler, M. A novel type of myosin implicated in signalling by rho family GTPases. EMBO J. 1995, 14, 697-704. [CrossRef]

143. Müller, R.T.; Honnert, U.; Reinhard, J.; Bähler, M. The Rat Myosin myr 5 Is a GTPase-activating Protein for Rho In Vivo: Essential Role of Arginine 1695. Mol. Biol. Cell 1997, 8, 2039-2053. [CrossRef] [PubMed]

144. Liu, K.C.; E Cheney, R. Myosins in cell junctions. BioArchitecture 2012, 2, 158-170. [CrossRef] [PubMed]

145. Wirth, J.A.; Jensen, K.A.; Post, P.L.; Bement, W.M.; Mooseker, M.S. Human myosin-IXb, an unconventional myosin with a chimerin-like rho/rac GTPase-activating protein domain in its tail. J. Cell Sci. 1996, 109 Pt 3, 653-661.

146. Wang, M.-J.; Xu, X.-L.; Yao, G.-L.; Yu, Q.; Zhu, C.-F.; Kong, Z.-J.; Zhao, H.; Tang, L.-M.; Qin, X.-H. MYO9B gene polymorphisms are associated with the risk of inflammatory bowel diseases. Oncotarget 2016, 7, 58862-58875. [CrossRef] [PubMed]

147. Hunt, K.A.; Monsuur, A.J.; McArdle, W.; Kumar, P.J.; Travis, S.P.L.; Walters, J.R.F.; Jewell, D.P.; Strachan, D.P.; Playford, R.J.; Wijmenga, C.; et al. Lack of association of MYO9B genetic variants with coeliac disease in a British cohort. Gut 2006, 55, 969-972. [CrossRef] [PubMed]

148. Hanley, P.J.; Xu, Y.; Kronlage, M.; Grobe, K.; Schoen, P.; Song, J.; Sorokin, L.; Schwab, A.; Baehler, M. Motorized RhoGAP myosin IXb (Myo9b) controls cell shape and motility. Proc. Natl. Acad. Sci. USA 2010, 107, 12145-12150. [CrossRef] [PubMed] 
149. Xu, Y.; Pektor, S.; Balkow, S.; Hemkemeyer, S.A.; Liu, Z.; Grobe, K.; Hanley, P.J.; Shen, L.; Bros, M.; Schmidt, T.; et al. Dendritic Cell Motility and T Cell Activation Requires Regulation of Rho-Cofilin Signaling by the Rho-GTPase Activating Protein Myosin IXb. J. Immunol. 2014, 192, 3559-3568. [CrossRef]

150. Long, H.; Zhu, X.; Yang, P.; Gao, Q.; Chen, Y.; Ma, L. Myo9b and RICS Modulate Dendritic Morphology of Cortical Neurons. Cereb. Cortex 2013, 23, 71-79. [CrossRef]

151. Govek, E.E.; Newey, S.E.; Akerman, C.J.; Cross, J.R.; Van der Veken, L.; Van Aelst, L. The X-linked mental retardation protein oligophrenin-1 is required for dendritic spine morphogenesis. Nat. Neurosci. 2004, 7, 364-372. [CrossRef]

152. Zanni, G.; Saillour, Y.; Nagara, M.; Billuart, P.; Castelnau, L.; Moraine, C.; Faivre, L.; Bertini, E.; Durr, A.; Guichet, A.; et al. Oligophrenin 1 mutations frequently cause X-linked mental retardation with cerebellar hypoplasia. Neurology 2005, 65, 1364-1369. [CrossRef]

153. Celestino-Soper, P.B.S.; Shaw, C.A.; Sanders, S.J.; Li, J.; Murtha, M.T.; Ercan-Sencicek, A.G.; Davis, L.; Thomson, S.; Gambin, T.; Chinault, A.C.; et al. Use of array CGH to detect exonic copy number variants throughout the genome in autism families detects a novel deletion in TMLHE. Hum. Mol. Genet. 2011, 20, 4360-4370. [CrossRef] [PubMed]

154. Piton, A.; Gauthier, J.; Hamdan, F.F.; Lafreniere, R.G.; Yang, Y.; Henrion, E.; Laurent, S.; Noreau, A.; Thibodeau, P.; Karemera, L.; et al. Systematic resequencing of X-chromosome synaptic genes in autism spectrum disorder and schizophrenia. Mol. Psychiatry 2011, 16, 867-880. [CrossRef] [PubMed]

155. Guo, H.; Duyzend, M.H.; Coe, B.P.; Baker, C.; Hoekzema, K.; Gerdts, J.; Turner, T.N.; Zody, M.C.; Beighley, J.S.; Murali, S.C.; et al. Genome sequencing identifies multiple deleterious variants in autism patients with more severe phenotypes. Genet. Med. 2019, 21, 1611-1620. [CrossRef] [PubMed]

156. Barresi, S.; Tomaselli, S.; Athanasiadis, A.; Galeano, F.; Locatelli, F.; Bertini, E.; Zanni, G.; Gallo, A. Oligophrenin-1 (OPHN1), a gene involved in X-linked intellectual disability, undergoes RNA editing and alternative splicing during human brain development. PLoS ONE 2014, 9, e91351. [CrossRef]

157. Fauchereau, F.; Herbrand, U.; Chafey, P.; Eberth, A.; Koulakoff, A.; Vinet, M.C.; Ahmadian, M.R.; Chelly, J.; Billuart, P. The RhoGAP activity of OPHN1, a new F-actin-binding protein, is negatively controlled by its amino-terminal domain. Mol. Cell. Neurosci. 2003, 23, 574-586. [CrossRef]

158. Redish, A.D. Vicarious trial and error. Nat. Rev. Neurosci. 2016, 17, 147-159. [CrossRef]

159. Burbelo, P.D.; Miyamoto, S.; Utani, A.; Brill, S.; Yamada, K.M.; Hall, A.; Yamada, Y. p190-B, a new member of the Rho GAP family, and Rho are induced to cluster after integrin cross-linking. J. Biol. Chem. 1995, 270, 30919-30926. [CrossRef]

160. Bustos, R.I.; Forget, M.-A.; Settleman, J.E.; Hansen, S.H. Coordination of Rho and Rac GTPase Function via p190B RhoGAP. Curr. Biol. 2008, 18, 1606-1611. [CrossRef]

161. Iossifov, I.; O’Roak, B.J.; Sanders, S.J.; Ronemus, M.; Krumm, N.; Levy, D.; Stessman, H.A.; Witherspoon, K.T.; Vives, L.; Patterson, K.E.; et al. The contribution of de novo coding mutations to autism spectrum disorder. Nature 2014, 515, 216-221. [CrossRef]

162. Stiegler, A.L.; Boggon, T.J. p190RhoGAP proteins contain pseudoGTPase domains. Nat. Commun. 2017, 8, 506. [CrossRef]

163. Héraud, C.; Pinault, M.; Lagrée, V.; Moreau, V. p190RhoGAPs, the ARHGAP35- and ARHGAP5-Encoded Proteins, in Health and Disease. Cells 2019, 8, 351. [CrossRef]

164. Sordella, R.; Classon, M.; Hu, K.Q.; Matheson, S.F.; Brouns, M.R.; Fine, B.; Zhang, L.; Takami, H.; Yamada, Y.; Settleman, J. Modulation of CREB activity by the Rho GTPase regulates cell and organism size during mouse embryonic development. Dev. Cell 2002, 2, 553-565. [CrossRef]

165. Matheson, S.F.; Hu, K.-Q.; Brouns, M.R.; Sordella, R.; VanderHeide, J.D.; Settleman, J. Distinct but overlapping functions for the closely related p190 RhoGAPs in neural development. Dev. Neurosci. 2006, 28, 538-550. [CrossRef] [PubMed]

166. Heckman, B.M.; Chakravarty, G.; Vargo-Gogola, T.; Gonzales-Rimbau, M.; Hadsell, D.L.; Lee, A.V.; Settleman, J.; Rosen, J.M. Crosstalk between the p190-B RhoGAP and IGF signaling pathways is required for embryonic mammary bud development. Dev. Biol. 2007, 309, 137-149. [CrossRef] [PubMed]

167. Raman, R.; Kumar, R.S.; Hinge, A.; Kumar, S.; Nayak, R.; Xu, J.; Szczur, K.; Cancelas, J.A.; Filippi, M.D. p190-B RhoGAP regulates the functional composition of the mesenchymal microenvironment. Leukemia 2013, 27, 2209-2219. [CrossRef] [PubMed] 
168. Hinge, A.; Xu, J.; Javier, J.; Mose, E.; Kumar, S.; Kapur, R.; Srour, E.F.; Malik, P.; Aronow, B.J.; Filippi, M.-D. p190-B RhoGAP and intracellular cytokine signals balance hematopoietic stem and progenitor cell self-renewal and differentiation. Nat. Commun. 2017, 8, 14382. [CrossRef] [PubMed]

169. Heide, M.; Long, K.R.; Huttner, W.B. Novel gene function and regulation in neocortex expansion. Curr. Opin. Cell Biol. 2017, 49, 22-30. [CrossRef]

170. Chiliana, B.; Abdollahpour, H.; Bierhals, T.; Haltrich, I.; Fekete, G.; Nagel, I.; Rosenberger, G.; Kutsche, K. Dysfunction of SHANK2 and CHRNA7 in a patient with intellectual disability and language impairment supports genetic epistasis of the two loci. Clin. Genet. 2013, 84, 560-565. [CrossRef]

171. Chen, J.; Calhoun, V.D.; Perrone-Bizzozero, N.I.; Pearlson, G.D.; Sui, J.; Du, Y.; Liu, J. A pilot study on commonality and specificity of copy number variants in schizophrenia and bipolar disorder. Transl. Psychiatry 2016, 6, e824. [CrossRef]

172. Vadgama, N.; Pittman, A.; Simpson, M.; Nirmalananthan, N.; Murray, R.; Yoshikawa, T.; De Rijk, P.; Rees, E.; Kirov, G.; Hughes, D.; et al. De novo single-nucleotide and copy number variation in discordant monozygotic twins reveals disease-related genes. Eur. J. Hum. Genet. 2019, 27, 1121-1133. [CrossRef]

173. Leblond, C.S.; Heinrich, J.; Delorme, R.; Proepper, C.; Betancur, C.; Huguet, G.; Konyukh, M.; Chaste, P.; Ey, E.; Rastam, M.; et al. Genetic and functional analyses of SHANK2 mutations suggest a multiple hit model of autism spectrum disorders. PLoS Genet. 2012, 8, e1002521. [CrossRef]

174. Florio, M.; Albert, M.; Taverna, E.; Namba, T.; Brandl, H.; Lewitus, E.; Haffner, C.; Sykes, A.; Wong, F.K.; Peters, J.; et al. Human-specific gene ARHGAP11B promotes basal progenitor amplification and neocortex expansion. Science 2015, 347, 1465-1470. [CrossRef] [PubMed]

175. Wilsch-Braeuninger, M.; Florio, M.; Huttner, W.B. Neocortex expansion in development and evolution - from cell biology to single genes. Curr. Opin. Neurobiol. 2016, 39, 122-132. [CrossRef] [PubMed]

176. Florio, M.; Namba, T.; Pääbo, S.; Hiller, M.; Huttner, W.B. A single splice site mutation in human-specific ARHGAP11B causes basal progenitor amplification. Sci. Adv. 2016, 2, e1601941. [CrossRef] [PubMed]

177. Akshoomoff, N.; Mattson, S.N.; Grossfeld, P.D. Evidence for autism spectrum disorder in Jacobsen syndrome: identification of a candidate gene in distal 11q. Genet. Med. 2015, 17, 143-148. [CrossRef] [PubMed]

178. Zhao, C.M.; Ma, H.; Bossy-Wetzel, E.; Lipton, S.A.; Zhang, Z.H.; Feng, G.S. GC-GAP, a Rho family GTPase-activating protein that interacts with signaling adapters Gab1 and Gab2. J. Biol. Chem. 2003, 278, 34641-34653. [CrossRef]

179. Okabe, T.; Nakamura, T.; Nishimura, Y.N.; Kohu, K.; Ohwada, S.; Morishita, Y.; Akiyama, T. RICS, a novel GTPase-activating protein for Cdc42 and Rac1, is involved in the beta-catenin-N-cadherin and N-methyl-D-aspartate receptor signaling. J. Biol. Chem. 2003, 278, 9920-9927. [CrossRef]

180. Nakamura, T.; Komiya, M.; Sone, K.; Hirose, E.; Gotoh, N.; Morii, H.; Ohta, Y.; Mori, N. Grit, a GTPase-activating protein for the Rho family, regulates neurite extension through association with the TrkA receptor and N-Shc and CrkL/Crk adapter molecules. Mol. Cell. Biol. 2002, 22, 8721-8734. [CrossRef]

181. Nakazawa, T.; Watabe, A.M.; Tezuka, T.; Yoshida, Y.; Yokoyama, K.; Umemori, H.; Inoue, A.; Okabe, S.; Manabe, T.; Yamamoto, T. p250GAP, a novel brain-enriched GTPase-activating protein for Rho family GTPases, is involved in the N-methyl-D-aspartate receptor signaling. Mol. Biol. Cell 2003, 14, 2921-2934. [CrossRef]

182. Moon, S.Y.; Zang, H.S.; Zheng, Y. Characterization of a brain-specific Rho GTPase-activating protein, p200RhoGAP. J. Biol. Chem. 2003, 278, 4151-4159. [CrossRef]

183. Nakamura, T.; Hayashi, T.; Nasu-Nishimura, Y.; Sakaue, F.; Morishita, Y.; Okabe, T.; Ohwada, S.; Matsuura, K.; Akiyama, T. PX-RICS mediates ER-to-Golgi transport of the N-cadherin/beta-catenin complex. Genes Dev. 2008, 22, 1244-1256. [CrossRef] [PubMed]

184. Nasu-Nishimura, Y.; Hayashi, T.; Ohishi, T.; Okabe, T.; Ohwada, S.; Hasegawa, Y.; Senda, T.; Toyoshima, C.; Nakamura, T.; Akiyama, T. Role of the Rho GTPase-activating protein RICS in neurite outgrowth. Genes Cells 2006, 11, 607-614. [CrossRef] [PubMed]

185. Yuan, J.; Huang, H.; Zhou, X.; Liu, X.; Ou, S.; Xu, T.; Li, R.; Ma, L.; Chen, Y. MicroRNA-132 Interact with p250GAP/Cdc42 Pathway in the Hippocampal Neuronal Culture Model of Acquired Epilepsy and Associated with Epileptogenesis Process. Neural Plast. 2016, 2016, 5108489. [CrossRef] [PubMed]

186. Hayashi, T.; Okabe, T.; Nasu-Nishimura, Y.; Sakaue, F.; Ohwada, S.; Matsuura, K.; Akiyama, T.; Nakamura, T. PX-RICS, a novel splicing variant of RICS, is a main isoform expressed during neural development. Genes Cells 2007, 12, 929-939. [CrossRef] 
187. Endris, V.; Wogatzky, B.; Leimer, U.; Bartsch, D.; Zatyka, M.; Latif, F.; Maher, E.R.; Tariverdian, G.; Kirsch, S.; Karch, D.; et al. The novel Rho-GTPase activating gene MEGAP/srGAP3 has a putative role in severe mental retardation. Proc. Natl. Acad. Sci. USA 2002, 99, 11754-11759. [CrossRef]

188. Ma, Y.; Mi, Y.-J.; Dai, Y.-K.; Fu, H.-L.; Cui, D.-X.; Jin, W.-L. The inverse F-BAR domain protein srGAP2 acts through srGAP3 to modulate neuronal differentiation and neurite outgrowth of mouse neuroblastoma cells. PLOS ONE 2013, 8, e57865. [CrossRef]

189. Bacon, C.; Endris, V.; Rappold, G.A. The cellular function of srGAP3 and its role in neuronal morphogenesis. Mech. Dev. 2013, 130, 391-395. [CrossRef]

190. Wuertenberger, S.; Groemping, Y. A single PXXP motif in the C-terminal region of srGAP3 mediates binding to multiple SH3 domains. FEBS Lett. 2015, 589, 1156-1163. [CrossRef]

191. Waltereit, R.; Kautt, S.; Bartsch, D. Expression of MEGAP mRNA during embryonic development. Gene Expr. Patterns 2008, 8, 307-310. [CrossRef]

192. Bacon, C.; Endris, V.; Rappold, G. Dynamic Expression of the Slit-Robo GTPase Activating Protein Genes during Development of the Murine Nervous System. J. Comp. Neurol. 2009, 513, 224-236. [CrossRef]

193. Yao, Q.; Jin, W.-L.; Wang, Y.; Ju, G. Regulated shuttling of Slit-Robo-GTPase activating proteins between nucleus and cytoplasm during brain development. Cell. Mol. Neurobiol. 2008, 28, 205-221. [CrossRef] [PubMed]

194. Faucherre, A.; Desbois, P.; Satre, V.; Lunardi, J.; Dorseuil, O.; Gacon, G. Lowe syndrome protein OCRL1 interacts with Rac GTPase in the trans-Golgi network. Hum. Mol. Genet. 2003, 12, 2449-2456. [CrossRef] [PubMed]

195. Kenworthy, L.; Park, T.; Charnas, L.R. Cognitive and behavioral profile of the oculocerebrorenal syndrome of Lowe. Am. J. Med Genet. 1993, 46, 297-303. [CrossRef] [PubMed]

196. Oliver, C.; Berg, K.; Moss, J.; Arron, K.; Burbidge, C. Delineation of Behavioral Phenotypes in Genetic Syndromes: Characteristics of Autism Spectrum Disorder, Affect and Hyperactivity. J. Autism Dev. Disord. 2011, 41, 1019-1032. [CrossRef] [PubMed]

197. Schroer, R.J.; Beaudet, A.L.; Shinawi, M.; Sahoo, T.; Patel, A.; Sun, Q.; Skinner, C.; Stevenson, R.E. Duplication of OCRL and Adjacent Genes Associated with Autism but not Lowe Syndrome. Am. J. Med. Genet. Part A 2012, 158A, 2602-2605. [CrossRef] [PubMed]

198. Erdmann, K.S.; Mao, Y.; McCrea, H.J.; Zoncu, R.; Lee, S.; Paradise, S.; Modregger, J.; Biemesderfer, D.; Toomre, D.; De Camillil, P. A role of the Lowe syndrome protein OCRL in early steps of the endocytic pathway. Dev. Cell 2007, 13, 377-390. [CrossRef]

199. Mao, Y.; Balkin, D.M.; Zoncu, R.; Erdmann, K.S.; Tomasini, L.; Hu, F.; Jin, M.M.; Hodsdon, M.E.; De Camilli, P. A PH domain within OCRL bridges clathrin-mediated membrane trafficking to phosphoinositide metabolism. EMBO J. 2009, 28, 1831-1842. [CrossRef]

200. Bothwell, S.P.; Chan, E.; Bernardini, I.M.; Kuo, Y.-M.; Gahl, W.A.; Nussbaum, R.L. Mouse Model for Lowe Syndrome/Dent Disease 2 Renal Tubulopathy. J. Am. Soc. Nephrol. 2011, 22, 443-448. [CrossRef]

201. Takai, Y.; Sasaki, T.; Matozaki, T. Small GTP-binding proteins. Physiol. Rev. 2001, 81, 153-208. [CrossRef]

202. Kitamura, Y.; Kitamura, T.; Sakaue, H.; Maeda, T.; Ueno, H.; Nishio, S.; Ohno, S.; Osada, S.i.; Sakaue, M.; Ogawa, W.; et al. Interaction of Nck-associated protein 1 with activated GTP-binding protein Rac. Biochem. J. 1997, 322 Pt 3, 873-878. [CrossRef]

203. Iossifov, I.; Ronemus, M.; Levy, D.; Wang, Z.; Hakker, I.; Rosenbaum, J.; Yamrom, B.; Lee, Y.-h.; Narzisi, G.; Leotta, A.; et al. De Novo Gene Disruptions in Children on the Autistic Spectrum. Neuron 2012, 74, 285-299. [CrossRef] [PubMed]

204. Iossifov, I.; Levy, D.; Allen, J.; Ye, K.; Ronemus, M.; Lee, Y.-h.; Yamrom, B.; Wigler, M. Low load for disruptive mutations in autism genes and their biased transmission. Proc. Natl. Acad. Sci. United States Am. 2015, 112, E5600-E5607. [CrossRef] [PubMed]

205. Freed, D.; Pevsner, J. The Contribution of Mosaic Variants to Autism Spectrum Disorder. PLoS Genet. 2016, 12, e1006245. [CrossRef] [PubMed]

206. Kitamura, T.; Kitamura, Y.; Yonezawa, K.; Totty, N.F.; Gout, I.; Hara, K.; Waterfield, M.D.; Sakaue, M.; Ogawa, W.; Kasuga, M. Molecular cloning of p125Nap1, a protein that associates with an SH3 domain of Nck. Biochem. Biophys. Res. Commun. 1996, 219, 509-514. [CrossRef] 
207. Suzuki, T.; Nishiyama, K.; Yamamoto, A.; Inazawa, J.; Iwaki, T.; Yamada, T.; Kanazawa, I.; Sakaki, Y. Molecular cloning of a novel apoptosis-related gene, human Nap1 (NCKAP1), and its possible relation to Alzheimer disease. Genomics 2000, 63, 246-254. [CrossRef]

208. Yokota, Y.; Ring, C.; Cheung, R.; Pevny, L.; Anton, E.S. Nap1-regulated neuronal cytoskeletal dynamics is essential for the final differentiation of neurons in cerebral cortex. Neuron 2007, 54, 429-445. [CrossRef]

209. Doornbos, M.; Sikkema-Raddatz, B.; Ruijvenkamp, C.A.L.; Dijkhuizen, T.; Bijlsma, E.K.; Gijsbers, A.C.J.; Hilhorst-Hofstee, Y.; Hordijk, R.; Verbruggen, K.T.; Kerstjens-Frederikse, W.S.; et al. Nine patients with a microdeletion 15q11.2 between breakpoints 1 and 2 of the Prader-Willi critical region, possibly associated with behavioural disturbances. Eur. J. Med. Genet. 2009, 52, 108-115. [CrossRef]

210. Van der Zwaag, B.; Staal, W.G.; Hochstenbach, R.; Poot, M.; Spierenburg, H.A.; de Jonge, M.V.; Verbeek, N.E.; van't Slot, R.; van Es, M.A.; Staal, F.J.; et al. A Co-segregating Microduplication of Chromosome 15q11.2 Pinpoints Two Risk Genes for Autism Spectrum Disorder. Am. J. Med. Genet. Part B Neuropsychiatr. Genet. 2010, 153B, 960-966. [CrossRef]

211. Picinelli, C.; Lintas, C.; Piras, I.S.; Gabriele, S.; Sacco, R.; Brogna, C.; Persico, A.M. Recurrent 15q11.2 BP1-BP2 Microdeletions and Microduplications in the Etiology of Neurodevelopmental Disorders. Am. J. Med. Genet. Part B Neuropsychiatr. Genet. 2016, 171, 1088-1098. [CrossRef]

212. Cox, D.M.; Butler, M.G. The 15q11.2 BP1-BP2 Microdeletion Syndrome: A Review. Int. J. Mol. Sci. 2015, 16, 4068-4082. [CrossRef]

213. Isabel Alvarez-Mora, M.; Calvo Escalona, R.; Puig Navarro, O.; Madrigal, I.; Quintela, I.; Amigo, J.; Martinez-Elurbe, D.; Linder-Lucht, M.; Aznar Lain, G.; Carracedo, A.; et al. Comprehensive molecular testing in patients with high functioning autism spectrum disorder. Mutat. Res. Fundam. Mol. Mech. Mutagenesis 2016, 784, 46-52. [CrossRef]

214. Waltes, R.; Duketis, E.; Knapp, M.; Anney, R.J.L.; Huguet, G.; Schlitt, S.; Jarczok, T.A.; Sachse, M.; Kaempfer, L.M.; Kleinboeck, T.; et al. Common variants in genes of the postsynaptic FMRP signalling pathway are risk factors for autism spectrum disorders. Hum. Genet. 2014, 133, 781-792. [CrossRef]

215. Toma, C.; Torrico, B.; Hervas, A.; Valdes-Mas, R.; Tristan-Noguero, A.; Padillo, V.; Maristany, M.; Salgado, M.; Arenas, C.; Puente, X.S.; et al. Exome sequencing in multiplex autism families suggests a major role for heterozygous truncating mutations. Mol. Psychiatry 2014, 19, 784-790. [CrossRef]

216. Wang, J.; Tao, Y.; Song, F.; Sun, Y.; Ott, J.; Saffen, D. Common Regulatory Variants of CYFIP1 Contribute to Susceptibility for Autism Spectrum Disorder (ASD) and Classical Autism. Ann. Hum. Genet. 2015, 79, 329-340. [CrossRef]

217. Noroozi, R.; Omrani, M.D.; Sayad, A.; Taheri, M.; Ghafouri-Fard, S. Cytoplasmic FMRP interacting protein 1/2 (CYFIP1/2) expression analysis in autism. Metab. Brain Dis. 2018, 33, 1353-1358. [CrossRef]

218. Kobayashi, K.; Kuroda, S.; Fukata, M.; Nakamura, T.; Nagase, T.; Nomura, N.; Matsuura, Y.; Yoshida-Kubomura, N.; Iwamatsu, A.; Kaibuchi, K. p140Sra-1 (specifically Rac1-associated protein) is a novel specific target for Rac1 small GTPase. J. Biol. Chem. 1998, 273, 291-295. [CrossRef]

219. De Rubeis, S.; Pasciuto, E.; Li, K.W.; Fernandez, E.; Di Marino, D.; Buzzi, A.; Ostroff, L.E.; Klann, E.; Zwartkruis, F.J.T.; Komiyama, N.H.; et al. CYFIP1 Coordinates mRNA Translation and Cytoskeleton Remodeling to Ensure Proper Dendritic Spine Formation. Neuron 2013, 79, 1169-1182. [CrossRef]

220. Koster, F.; Schinke, B.; Niemann, S.; Hermans-Borgmeyer, I. Identification of shyc, a novel gene expressed in the murine developing and adult nervous system. Neurosci. Lett. 1998, 252, 69-71. [CrossRef]

221. Bonaccorso, C.M.; Spatuzza, M.; Di Marco, B.; Gloria, A.; Barrancotto, G.; Cupo, A.; Musumeci, S.A.; D'Antoni, S.; Bardoni, B.; Catania, M.V. Fragile X mental retardation protein (FMRP) interacting proteins exhibit different expression patterns during development. Int. J. Dev. Neurosci. 2015, 42, 15-23. [CrossRef]

222. Hsiao, K.; Harony-Nicolas, H.; Buxbaum, J.D.; Bozdagi-Gunal, O.; Benson, D.L. Cyfip1 Regulates Presynaptic Activity during Development. J. Neurosci. 2016, 36, 1564-1576. [CrossRef]

223. Pathania, M.; Davenport, E.C.; Muir, J.; Sheehan, D.F.; López-Doménech, G.; Kittler, J.T. The autism and schizophrenia associated gene CYFIP1 is critical for the maintenance of dendritic complexity and the stabilization of mature spines. Transl. Psychiatry 2014, 4, e374. [CrossRef]

224. Davenport, E.C.; Szulc, B.R.; Drew, J.; Taylor, J.; Morgan, T.; Higgs, N.F.; Lopez-Domenech, G.; Kittler, J.T. Autism and Schizophrenia-Associated CYFIP1 Regulates the Balance of Synaptic Excitation and Inhibition. Cell Rep. 2019, 26, 2037. [CrossRef] 
225. Yuen, R.K.C.; Merico, D.; Bookman, M.; Howe, J.L.; Thiruvahindrapuram, B.; Patel, R.V.; Whitney, J.; Deflaux, N.; Bingham, J.; Wang, Z.; et al. Whole genome sequencing resource identifies 18 new candidate genes for autism spectrum disorder. Nat. Neurosci. 2017, 20, 602. [CrossRef]

226. Willatt, L.; Cox, J.; Barber, J.; Cabanas, E.D.; Collins, A.; Donnai, D.; FitzPatrick, D.R.; Maher, E.; Martin, H.; Parnau, J.; et al. 3q29 Microdeletion syndrome: Clinical and molecular characterization of a new syndrome. Am. J. Hum. Genet. 2005, 77, 154-160. [CrossRef]

227. Quintero-Rivera, F.; Sharifi-Hannauer, P.; Martinez-Agosto, J.A. Autistic and Psychiatric Findings Associated With the 3q29 Microdeletion Syndrome: Case Report and Review. Am. J. Med Genet. Part A 2010, 152A, 2459-2467. [CrossRef]

228. Glassford, M.R.; Rosenfeld, J.A.; Freedman, A.A.; Zwick, M.E.; Mulle, J.G. Novel features of 3q29 deletion syndrome: Results from the 3q29 registry. Am. J. Med Genet. Part A 2016, 170, 999-1006. [CrossRef]

229. Jaffer, Z.M.; Chernoff, J. p21-activated kinases: three more join the Pak. Int. J. Biochem. Cell Biol. 2002, 34, 713-717. [CrossRef]

230. Rane, C.K.; Minden, A. P21 activated kinases: structure, regulation, and functions. Small Gtpases 2014, 5, e28003. [CrossRef]

231. Kreis, P.; Barnier, J.-V. PAK signalling in neuronal physiology. Cell. Signal. 2009, 21, 384-393. [CrossRef]

232. Arias-Romero, L.E.; Chernoff, J. A tale of two Paks. Biol. Cell 2008, 100, 97-108. [CrossRef]

233. Hofmann, C.; Shepelev, M.; Chernoff, J. The genetics of Pak. J. Cell Sci. 2004, 117, 4343-4354. [CrossRef]

234. Marlin, J.W.; Chang, Y.-W.E.; Ober, M.; Handy, A.; Xu, W.; Jakobi, R. Functional PAK-2 knockout and replacement with a caspase cleavage-deficient mutant in mice reveals differential requirements of full-length PAK-2 and caspase-activated PAK-2p34. Mamm. Genome 2011, 22, 306-317. [CrossRef]

235. Geisheker, M.R.; Heymann, G.; Wang, T.; Coe, B.P.; Turner, T.N.; Stessman, H.A.F.; Hoekzema, K.; Kvarnung, M.; Shaw, M.; Friend, K.; et al. Hotspots of missense mutation identify neurodevelopmental disorder genes and functional domains. Nat. Neurosci. 2017, 20, 1043. [CrossRef]

236. Patel, S.; Joseph, S.K.; Thomas, A.P. Molecular properties of inositol 1,4,5-trisphosphate receptors. Cell Calcium 1999, 25, 247-264. [CrossRef]

237. Rosemblit, N.; Moschella, M.C.; Ondriasova, E.; Gutstein, D.E.; Ondrias, K.; Marks, A.R. Intracellular calcium release channel expression during embryogenesis. Dev. Biol. 1999, 206, 163-177. [CrossRef]

238. Nakanishi, S.; Maeda, N.; Mikoshiba, K. Immunohistochemical localization of an inositol 1,4,5-trisphosphate receptor, P400, in neural tissue: studies in developing and adult mouse brain. J. Neurosci. 1991, 11, 2075-2086. [CrossRef]

239. Taylor, C.W.; Genazzani, A.A.; Morris, S.A. Expression of inositol trisphosphate receptors. Cell Calcium 1999, 26, 237-251. [CrossRef]

240. Matsumoto, M.; Nakagawa, T.; Inoue, T.; Nagata, E.; Tanaka, K.; Takano, H.; Minowa, O.; Kuno, J.; Sakakibara, S.; Yamada, M.; et al. Ataxia and epileptic seizures in mice lacking type 1 inositol 1,4,5-trisphosphate receptor. Nature 1996, 379, 168-171. [CrossRef]

241. Inoue, T.; Kato, K.; Kohda, K.; Mikoshiba, K. Type 1 inositol 1,4,5-trisphosphate receptor is required for induction of long-term depression in cerebellar Purkinje neurons. J. Neurosci. 1998, 18, 5366-5373. [CrossRef]

242. Fujii, S.; Matsumoto, M.; Igarashi, K.; Kato, H.; Mikoshiba, K. Synaptic plasticity in hippocampal CA1 neurons of mice lacking type 1 inositol-1,4,5-trisphosphate receptors. Learn. Mem. 2000, 7, 312-320. [CrossRef]

243. Nagase, T.; Ito, K.I.; Kato, K.; Kaneko, K.; Kohda, K.; Matsumoto, M.; Hoshino, A.; Inoue, T.; Fujii, S.; Kato, H.; et al. Long-term potentiation and long-term depression in hippocampal CA1 neurons of mice lacking the IP3 type 1 receptor. Neuroscience 2003, 117, 821-830. [CrossRef]

244. Steinberg, S.F. Structural basis of protein kinase C isoform function. Physiol. Rev. 2008, 88, 1341-1378. [CrossRef]

245. Singh, R.K.; Kumar, S.; Gautam, P.K.; Tomar, M.S.; Verma, P.K.; Singh, S.P.; Kumar, S.; Acharya, A. Protein kinase C-alpha and the regulation of diverse cell responses. Biomol. Concepts 2017, 8, 143-153. [CrossRef]

246. Shuntoh, H.; Sakamoto, N.; Matsuyama, S.; Saitoh, M.; Tanaka, C. Molecular structure of the C beta catalytic subunit of rat cAMP-dependent protein kinase and differential expression of $\mathrm{C}$ alpha and $\mathrm{C}$ beta isoforms in rat tissues and cultured cells. Biochim. Et Biophys. Acta 1992, 1131, 175-180. [CrossRef]

247. Letiges, M.; Plomann, M.; Standaert, M.L.; Bandyopadhyay, G.; Sajan, M.P.; Kanoh, Y.; Farese, R.V. Knockout of PKC alpha enhances insulin signaling through PI3K. Mol. Endocrinol. 2002, 16, 847-858. 
248. Ito, Y.; Carss, K.J.; Duarte, S.T.; Hartley, T.; Keren, B.; Kurian, M.A.; Marey, I.; Charles, P.; Mendonca, C.; Nava, C.; et al. De Novo Truncating Mutations in WASF1 Cause Intellectual Disability with Seizures. Am. J. Hum. Genet. 2018, 103, 144-153. [CrossRef]

249. Benachenhou, N.; Massy, I.; Vacher, J. Characterization and expression analyses of the mouse Wiskott-Aldrich syndrome protein (WASP) family member Wave1/Scar. Gene 2002, 290, 131-140. [CrossRef]

250. Suetsugu, S.; Miki, H.; Takenawa, T. Identification of two human WAVE/SCAR homologues as general actin regulatory molecules which associate with the Arp2/3 complex. Biochem. Biophys. Res. Commun. 1999, 260, 296-302. [CrossRef]

251. Dahl, J.P.; Wang-Dunlop, J.; Gonzalez, C.; Goad, M.E.P.; Mark, R.J.; Kwak, S.P. Characterization of the WAVE1 knock-out mouse: Implications for CNS development. J. Neurosci. 2003, 23, 3343-3352. [CrossRef]

252. Ceglia, I.; Lee, K.-W.; Cahill, M.E.; Graves, S.M.; Dietz, D.; Surmeier, D.J.; Nestler, E.J.; Nairn, A.C.; Greengard, P.; Kim, Y. WAVE1 in neurons expressing the D1 dopamine receptor regulates cellular and behavioral actions of cocaine. Proc. Natl. Acad. Sci. USA 2017, 114, 1395-1400. [CrossRef]

253. Varghese, M.; Keshav, N.; Jacot-Descombes, S.; Warda, T.; Wicinski, B.; Dickstein, D.L.; Harony-Nicolas, H.; De Rubeis, S.; Drapeau, E.; Buxbaum, J.D.; et al. Autism spectrum disorder: neuropathology and animal models. Acta Neuropathol. 2017, 134, 537-566. [CrossRef] [PubMed]

254. Petrelli, F.; Pucci, L.; Bezzi, P. Astrocytes and Microglia and Their Potential Link with Autism Spectrum Disorders. Front. Cell. Neurosci. 2016, 10, 21. [CrossRef] [PubMed]

255. Matta, S.M.; Hill-Yardin, E.L.; Crack, P.J. The influence of neuroinflammation in Autism Spectrum Disorder. Brain Behav. Immun. 2019, 79, 75-90. [CrossRef]

256. Delorme, R.; Ey, E.; Toro, R.; Leboyer, M.; Gillberg, C.; Bourgeron, T. Progress toward treatments for synaptic defects in autism. Nat. Med. 2013, 19, 685-694. [CrossRef]

(C) 2020 by the authors. Licensee MDPI, Basel, Switzerland. This article is an open access article distributed under the terms and conditions of the Creative Commons Attribution (CC BY) license (http://creativecommons.org/licenses/by/4.0/). 